\title{
DRAMATYZOWANE HOMILIE PATRYSTYCZNE ZALĄŻKIEM DRAMATU CHRZEŚCIJAŃSKIEGO
}

Przyjmuje się dziś ogólnie, że dramat chrześcijański nie rozwinął się z bezpośredniej ewolucji lub kontynuacji greckiego lub łacińskiego dramatu klasycznego, ale z dramatyzowanej homilii patrystycznej. O jej strukturze, cechach i rodzajach pisaliśmy już wcześniej ${ }^{1}$, obecnie zaś chcemy przybliżyć i w miarę możliwości jak najobficiej udokumentować właściwą i w pełni udramatyzowaną w formie i treści samą homilię patrystyczną, w której występują większe lub mniejsze autentyczne (przejęte wprost z Biblii) albo oparte na nich wyimaginowane, uzupełnione przez kaznodzieję, dialogi oraz akcja z dodanymi nierzadko scenami pełnymi ruchu i dramatyzmu. Ze względu na treść tego rodzaju dramatyzowane homilie patrystyczne można najogólniej podzielić, jak przed laty sugerował Giorgio La Piana ${ }^{2}$, na trzy zasadnicze grupy: I. Homilie o Janie Chrzcicielu i chrzcie Chrystusa w Jordanie, II. Homilie o zstąpieniu Chrystusa do otchłani i uwolnieniu przebywających tam Patriarchów, i wreszcie najliczniejsze - III. Homilie o zwiastowaniu i wątpliwościach św. Józefa. Ze względu na rozległość tematu w tym przyczynku zaprezentujemy tylko dwie pierwsze grupy dramatyzowanych homilii patrystycznych.

\section{HOMILIE O JANIE CHRZCICIELU I CHRZCIE CHRYSTUSA ${ }^{3}$}

Chrzest Chrystusa nad Jordanem był jednym z najczęściej poruszanych tematów przez kaznodziejów wczesnochrześcijańskich, którzy zwłaszcza na Wschodzie, pozostawili nam wiele homilii na ten temat. Noszą one zazwyczaj

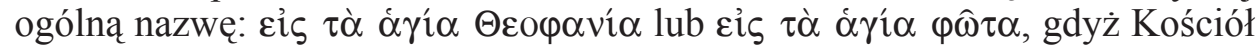

${ }^{*}$ Ks. dr hab. Stanisław Longosz - emerytowany profesor Katolickiego Uniwersytetu Lubelskiego Jana Pawła II; były dyrektor Instytutu Badań nad Antykiem Chrześcijańskim KUL oraz redaktor naczelny „Vox Patrum”; e-mail: longosz1@interia.pl.

${ }^{1}$ Por. S. Longosz, Zalażki dramatu chrześcijańskiego w literaturze patrystycznej, RH 44 (1996) z. 3, 263-273, spec. 268-271; G. La Piana, Le rappresentazioni sacre nella letteratura bizantina, Grottaferrata 1912, 70-72; S. Longosz, Póldramatyczne homilie patrystyczne, w: W postudze Stowa Pańskiego. Księga Pamiqtkowa ks. prof. J .Kudasiewicza, Kielce 1997, 422-437, spec. 423-424; J. Kecskeméti, L’homélie dramatisée dans la prédication grecque, CPE 1999, $\mathrm{nr} 74,20-32$

${ }^{2}$ Por. La Piana, Le rappresentazioni sacre, s. 69.

${ }^{3}$ Por. S. Longosz, Dramatyzowane homilie o Janie Chrzcicielu i chrzcie Chrystusa, VoxP 23 (2003) t. 44-45, 65-75. 
Grecki obchodząc uroczyście chrzest Chrystusa w Epifanię, używał w tym dniu wiele zapalonych świateł w swych świątyniach, dla usymbolizowania światła Ducha Świętego, wylanego na dusze nowo ochrzczonych w tym czasie. Ewangeliczny opis chrztu Chrystusa (Mt 3, 13-17; Mk 1, 9-11; Łk 3, 2122; J 1, 31-34) zawiera w sobie krótkie dialogi i pewną dramaturgię, którą wczesnochrześcijańscy homileci chętnie poszerzali i rozbudowywali. Spośród licznych homilii na ten temat wybieramy tu tylko dwie, w których dopatrzyliśmy się wyraźnych znamion dramatycznych.

1. Homilia na św. Teofanię lub o chrzcie Chrystusa, przypisywana błędnie św. Grzegorzowi Cudotwórcy $(† 270)^{4}$. W jej wstępie kaznodzieja zachęca słuchaczy do przeniesienia się w myślach z Galilei do Judei, nad brzegi Jordanu, gdzie plastycznie opisuje udzielanie chrztu pokuty przez Jana Chrzciciela: z thumu wyłania się Chrystus, co jest uobecnione przez przytoczony tekst biblijny (Mt 3, 13), a chór w nawiązaniu do niego wychwala miłość Boga, który się upokarza przez zmieszanie się z thumem i oczekiwanie na chrzest pokuty. Kaznodzieja szczegółowo opisuje dalej, jak Jan rozpoznaje Chrystusa i głęboko wzruszony prowadzi z nim długi dialog, składający się z trzech zasadniczych części, niby trzech odsłon lub scen, poprzedzanych regularnie przez trzy wersety, zaczerpnięte z ewangelicznego opisu Jego chrztu:

A. ,Ja potrzebuję chrztu od Ciebie, a Ty przychodzisz do mnie” (Mt 3,14) - Jan poprzez serię pytań i pełnych retoryki antytez wyraża swą pokorę, iż nie odważy się podnieść ręki i chrzcić swego Stwórcę:

„Co czynisz, Panie? Dlaczego odwracasz porządek rzeczy? Dlaczego ze sługami prosisz swego sługę o to, co jest powinnością sługi? Dlaczego chcesz otrzymać to, czego nie potrzebujesz? Dlaczego tak wielką łaskawością i pokora mnie sługę Twego przytłaczasz? [...]. Nie potrzebujesz chrztu ode mnie. Pochodnia bowiem od słońca jest rozpalana, a nie słońce od pochodni rozświetlane. Glina przez garncarza jest przygotowywana, a nie garncarz przez glinę formowany. Stworzenie przez Stwórce jest odnawiane, a nie Stwórca przez stworzenie. Chory przez lekarza jest leczony, a nie lekarz przez chorego pielęgnowany. Ubogi u bogatego pożycza, a nie bogaty u ubogiego [...]. Wiem dobrze, kim jesteś i skąd przychodzisz" (1180B-C).

B. „Nie jestem godzien rozwiązać rzemyka u Jego sandałów” (J 1, 27). Jan Chrzciciel jest w tej części przedstawiony jako teolog, który wyznaje swą wiarę

${ }^{4}$ Homilia in sanctam Theophaniam sive de Christi baptismo, PG 10, 1177-1190, thum. S. Longosz (jeśli nie podano nazwiska tłumacza, jest nim autor niniejszego artykułu; ponieważ znakomita większość cytowanych homilii nie ma podziału na rozdziały, przy podawaniu ich tłumaczonych fragmentów, wskazujemy tylko kolumny PG, na których się one znajdują). Homilia zawiera w sobie naukę i wyrażenia, które zdradzają dyskusje i język teologiczny V i VI w. i dlatego jej powstanie trzeba umieścić pod koniec V lub w VI w.; por. La Piana, Le rappresentazioni sacre, s. 73-76; Longosz, Dramatyzowane homilie o Janie Chrzcicielu, s. 67-70. 
w różne prawdy teologiczne: w bóstwo Chrystusa, w Jego bosko-ludzką naturę i Jego relacje z Ojcem. Ale i w tej teologicznej, na pozór abstrakcyjnej części, nie brakuje pewnego wdzięku i żywości dramatycznej, jak o tym na przykład świadczy wewnętrzna rozterka Jana:

„W czyje imię mam Cię ochrzcić? W imię Ojca? - przecież Ty masz całego Ojca w sobie i cały jesteś w Ojcu. Czy w imię Syna? - przecież oprócz Ciebie nie ma innego Syna Bożego z natury. Czy w imię Ducha Świętego? - przecież i On jest razem z Tobą jako Ci wspólistotny oraz tej samej woli i myśli, równy we władzy i równy we czci: razem z Tobą odbiera uwielbienie od wszystkich" (1184B).

C. „Oto Baranek Boży, który gładzi grzech świata” (J 1, 29). W tej wreszcie części kaznodzieja wznosi mowę Jana do wielkich nadziei odkupienia i zachęca wszystkie stworzenia do radości, bo zbliża się zbawienie świata. Chrystus odpowiada na to: „Pozwól teraz, bo tak godzi się nam wypełnić wszystko, co sprawiedliwe” (Mt 3, 15) i nakazuje milczeć Janowi, uzasadniając długo, że jeszcze nie nadszedł czas ujawnienia Jego bóstwa, i żeby szatan niczego nie podejrzewał:

„Udziel mi koniecznie chrztu, abym mógł zbawić ludzi. Udziel mi chrztu tak, jak Dziewica udzieliła mi swego mleka. Ujmij i dotknij mą głowę, którą uwielbiają Serafinowie. Ujmij swą prawą ręką moją głowę, która przez krew jest ci pokrewna [...]. Ochrzcij mnie, a ja w przyszłości będę chrzcił woda, Duchem i ogniem" (1187A).

Po tych słowach Jan zrozumiał wielką tajemnicę i drżącą ręką jak objaśnia kaznodzieja, chrzci Jezusa. Stojący zaś obok żydzi, obserwując co się dzieje, i słuchając tych rozmów, zaczęli między sobą szemrać:

„Czyż darmo podejrzewaliśmy, że Jan jest mocniejszy i doskonalszy od Jezusa? Czyż sam chrzest Jana nie świadczy, kto jest potężniejszy? Przecież chrzciciel jest wyższy godnością od chrzczonego" (1188B).

Wątpliwości te jednak przerywa głos z nieba:

„«Ten jest Syn mój miły» (Mt 3, 17). Jest nim Jezus, a nie Jan, chrzczony, a nie ten, który chrzci, zrodzony ze Mnie przed czasem, a nie z Zachariasza" (1188B-C).

Szeroko skomentowanymi słowami Ojca kaznodzieja kończy swą homilię, dołączając do niej tradycyjną doksologię.

W przedstawionej wyżej treści homilii łatwo zauważyć, że formę dramatyczną ma ona zwłaszcza w drugiej swej części. Przemawia w niej aż 6 postaci, które mają swe sprecyzowane wypowiedzi: Jezus, Jan, głos Boga, thum szemrających żydów, chór i mówca. Akcja jest jasno zaznaczona, dialogi mimo rozwlekłości i abstrakcyjnej treści teologicznej, zachowują swą dramatyczną 
żywość, która bardziej pasuje do jakiejś recytacji, niż do zwyczajnej prostej homilii. Jej treść mieści się na ogół w narracji ewangelicznej o chrzcie Chrystusa, z tym, że kaznodzieja oprócz wielorakiego rozbudowania krótkich dialogów ewangelicznych, wprowadza do akcji nową, nie wymienianą tam postać - grupę szemrających żydów. Jest to niewątpliwie jeden z pierwszych kroków uniezależniania się treści homilii dramatycznych od tekstu ewangelicznego i czerpania także z tradycji ludowych i apokryficznych, nie ograniczania się wyłącznie do autentycznych źródeł biblijnych.

2. Homilia o chrzcie Chrystusa - XI mowa autorstwa Pseudo-Euzebiusza Aleksandryjskiego (V/VI w. $)^{5}$, rzekomego następcy Cyryla Aleksandryjskiego († 444). W pierwszej swej części, która odpowiadałaby pierwszemu aktowi dramatu, jest ona krótkim streszczeniem wyżej scharakteryzowanej homilii o Teofanii: identyczne sytuacje, ten sam układ wydarzeń, podobne dialogi, te same pojęcia, a nawet kilkakrotnie te same słowa, zdają się wskazywać na ich wspólne źródło. Tuż jednak po tak lakonicznie opisanym chrzcie Chrystusa, pojawia się nowa postać - zaniepokojony tymi wydarzeniami szatan, i wówczas zaczyna się jakby drugi akt dramatu, złożony z prologu i trzech scen. Najpierw szatan, który przed chrztem nie znał Chrystusa i uważał Go za zwykłego narodzonego z kobiety człowieka, widząc wydarzenia nad Jordanem niepokoi się i pełen lęku prowadzi ze sobą dialog:

„Kim on jest? Wiem, że jest synem Maryi i cieśli Józefa. Skądże teraz słyszę takie rzeczy o nim? Czy nie jest to przypadkiem Chrystus? Czy nie jest to może ten, który ma odkupić świat? Czy nie jest on może Słowem, które było na początku, któremu ja się sprzeniewierzyłem, i przez które zostałem strącony na ziemię? Nie wierzę, żeby ten, który własnymi rękami kształtował ciało, przybrał teraz ciało człowieka. Co mam czynić? W jaki sposób mam się dokładniej dowiedzieć, czy on rzeczywiście jest Słowem, a jeśli jest nim naprawdę, to czy przyszedł, żeby mnie obalić? Biada ml biednemu, bo zmaleje moja władza, stępieje moja walka, i osłabnie moja moc" (376C).

W wyniku tych wątpliwości szatan postanawia sam wypróbować Jezusa i przekonać się, czy jest on zwykłym człowiekiem, czy też obiecanym Mesjaszem:

„Będę go kusił. Jeśli jest Synem Bożym, powie mi, nie pozwoli się przeze mnie kusić i słowem - uniknie mnie. Jeśli zaś przez kuszenie poznam, że nim nie jest, i nic z tych rzeczy, które Jan odważył się o nim głosić nie musi mnie smucić, powiem mu, żeby na przyszłość takich rzeczy już nie mówił [...]. Boje się jednak głosu z nieba, żeby nie okazał się prawdziwy" (376D).

${ }^{5}$ Homilia de baptismo [CPG 5520], PG 86, 372-380; por. La Piana, Le rappresentazioni sacre, s. 76-79; G. Lafontaine, Les homélies d'Eusèbe d'Alexandrie, Diss., Louvain 1966, 132; Longosz, Dramatyzowane homilie o Janie Chrzcicielu, s. 70-72 + przekład homilii dokonany przez T. Krynicką (s. 72-75). 
Po tym jakby prologu, rozpoczyna się pierwsza scena, ale w zmienionej już scenerii: nie jesteśmy już nad brzegami Jordanu, ale na szczycie wysokiej góry. Szatan wyprowadził tam Jezusa i jakby upojony swą władza, pewny siebie, pokazuje mu z wysoka wszystkie królestwa ziemi mówiąc: „Oddam ci to wszystko, jeśli upadniesz i oddasz mi pokłon" (Mt 4, 9). W odpowiedzi na tę propozycję zdaje się wkraczać chór, który z prawdziwym dramatycznym polotem i wyczuciem wyraża swe oburzenie wołając:

„Co ty mówisz, bezczelny szatanie? Obiecujesz Stwórcy wszystkiego oddać rzeczy stworzone? Ty Królowi królów ofiarujesz królestwo? [...]. Spójrzcie, Kochani, jak nędzna jest propozycja przebiegłego szatana i głupi pomysł? Od początku wiedział, że rodzaj ludzki jest chciwy i żądny władzy i dlatego właśnie tak go kusi” (377A).

Chrystus jednak nie oburza się i nie odpędza kusiciela, ale spokojnie odpowiada słowami ewangelicznego tekstu: „Napisane jest, będziesz czcił Pana Boga Twego i Jemu samemu będziesz służył" (Mt 4, 10). Po tej pokusie sceneria znów się zmienia: mówca przenosi sytuację na pustynię, gdzie Chrystus przez 40 dni pościł. Szatan wraca do kuszenia i udając ironicznie współczucie, sugeruje głodnemu Chrystusowi: „Jeśli jesteś Synem Bożym, powiedz, żeby te kamienie stały się chlebem" (Mt 4, 3). Zanim Chrystus odpowie, znowu zdaje się wkraczać chór, wyrażający swe oburzenie:

„Bezbożny szatanie! Ten ku któremu zwracają się oczy wszystkich, który w należytym czasie karmi wszystkich swym pokarmem, nie mógłby z kamieni uczynić chleba? Ten, który Izraelitom na pustyni zsyłał za darmo mannę, nie mógłby, nędzny diable, z kamieni uczynić chleba? Ten, który zaledwie tylko rzekł, a niebo, ziemia i całe stworzenie z niczego powstały, kamienie zaś dzięki Jego słowom nie stałyby się chlebem? Na pewno by się stały" (377C).

I tym razem Chrystus spokojnie odpowiada: „Nie samym chlebem żyje człowiek, ale każdym słowem Bożym" (Mt 4, 4).

Wreszcie zgodnie $\mathrm{z}$ ewangelicznym opowiadaniem sceneria homilii zmienia się po raz trzeci: kuszący szatan przenosi Chrystusa na narożnik świątyni i sugeruje Mu: „Jeśli jesteś Synem Bożym, rzuć się w dół” (Mt 4, 6). Tym razem jednak Chrystus uchyla nieco rąbka swego skrywanego bóstwa i pełnym władzy głosem odpowiada: „Idź precz szatanie! Jest napisane: nie będziesz kusił Pana Boga swego" (Mt 4, 7). Wówczas pokonany szatan ucieka, a chór intonuje kantyk pochwalny zakończony trisagionem. Kaznodzieja zaś kończy swą homilię uwagą, że Jezus ukrywał swe bóstwo po to, aby odnieść większy triumf nad szatanem i wyrwać nas z jego rąk.

Oceniając drugą interesującą nas szczególnie część homilii, którą porównaliśmy na wstępie do drugiego aktu dramatu, trzeba zauważyć, że jej autor respektuje na ogół schemat opowiadania ewangelicznego, choć w celach dramatycznych zmienił nieco porządek kuszeń, stawiając na ostatnim miejscu 
pokusę, którą ewangelista umieścił na drugim, aby przez to zamknąć dramat deklaracją ujawniającą bóstwo Chrystusa. Także solilokwium diabła przed kuszeniem Chrystusa jest wyjątkowo dramatyczne: jego lęki i obawy, wyrażane serią okrzyków i biadań, jeśliby Chrystus okazał się Synem Bożym, ośmieszają go i wywołuja przynajmniej dobry humor u słuchaczy. Najpiękniejszą niewątpliwie jest sama sceneria kuszeń: różnorodność scen, które się przenoszą z miejsca na miejsce, uroczysta powaga Jezusowego języka w zestawieniu z gadatliwością szatana oraz interwencja chóru z gwałtownymi apostrofami do kusiciela, wszystko to nadaje dramatowi mistyczną powagę, która wzrusza głęboko każdego, mimo rudymentalnej techniki i prostoty dramatycznego procesu. Trzy sceny kuszenia są jednak w porównaniu z poprzedzającym je prologiem (solilokwium szatana) stosunkowo krótkie i schematyczne, i być może są również, podobnie jak pierwsza część homilii, zwięzłym streszczeniem jakiejś wcześniejszej obszerniejszej redakcji.

\section{HOMILIE O ZSTĄPIENIU DO OTCHŁANI}

Ich tematyka oparta jest na drobnych, lakonicznych nowotestamentalnych wzmiankach (por. Mt 12, 40; 27, 52-53; Dz 2, 27 i 31; Rz 10, 6-7; Ef 4, 8-10; 1P 3, 19; 4, 6; Hbr 13, 20; Ap 1, 18), informujących o tajemniczym zstapieniu Chrystusa po śmierci na krzyżu do otchłani i nawiedzeniu przebywających tam sprawiedliwych zmarłych, które niewątpliwie miały też znamiona starotestamentalne (1Krl 2, 6; Hi 21, 23), deklarujące, że umrzeć to po prostu nieodwołalnie ,zstąpić do szeolu” (= hadesu, otchłani, piekieł $)^{6}$. Te biblijne

${ }^{6}$ Por. S. Kowalski, Le problème de la descente du Christ aux enfers dans la I Épitre de S. Pierre, CT 21 (1949) 42-76; J. Teixidor, La descente aux Enfers chez saint Éphrem, „L'Orient Syrien” 6 (1961) 25-40; W. Maas, Gott und Hölle. Studien zum Descensus Christi, Erlangen 1979; W. Hryniewicz, ,Zstapienie do piekiet” w tradycji wschodniej, RTK 26 (1979) z. 3, 41-52; R. Rubinkiewicz, ,Duchy zamknięte w więzieniu”. Interpretacje 1P 3, 41 9-20 w świetle Hen 10, 4, 2, RTK 28 (1981) z. 1, 77-86; A. Nosol, „Zstapił do piekiet”, AK 98 (1982) 170-178, „Communio” 5 (1985) z. 1 (cały zeszyt temu poświęcony, autorzy: W. Maas, H.U. Balthasar, F. Szulc, S. Cipriani, L. Balter, F. Lange); S. Piotrowski, Teologiczne treści formuly „Zstapił do piekiet”, „Wiadomości Kościelne Archidiecezji w Białymstoku” 18 (1992) 71-77; H. Pietras, Kerygmatyczna treść formuly „Zstapit do piekiet" u pierwszych Ojców, w: Ewangelizacja w epoce patrystycznej. Zagadnienia wybrane, red. F. Drączkowski - J. Pałucki, Lublin 1994, 103-123; M. Simonetti, Praecursor ad inferos. Una nota sull'interpretazione patristica di Matteo 11, 3, „Augustinianum” 20 (1980) 369-371; W. Hall Harris, The Descent of Christ, New York 1996; R. Gounelle, La Descente du Christ aux enfers, Paris 2000; G. Bendinelli, Origene e il „,descensus ad inferos”, „Divus Thomas” 104 (2001) 183-210; M.F. Connell, ,Descensus Christi ad inferos”. Christ's Descend to the Dead, ThS 62 (2001) 262282; S. Skrzyniarz, Hades. Recepcja, sens ideowy i przemiany obrazu pogańskiego boga w sztuce bizantyńskiej, Kraków 2002, spec. s. 48-80 (Zstapienie Chrystusa do otchłani); M. Mejzner, ,Zstapienie do piekiet” w starożytności chrześcijańskiej, „Communio” 31 (2011) z. 2, 90-108; K. Góźdź, „Descensus ad inferos”, „Communio” 33 (2013) z. 3, 129-140; P. Callon, Descente du Christ aux enfers, w: Catholicisme III 658-661; E. Peretto, Discesa agli inferi, DPAC I 989-991; R. Zając T. Dola, Zstapienie Chrystusa do otchtani, EK XX 1485-1488. 
wzmianki komentowali później od początku autorzy wczesnochrześcijańscy (m.in. Hermas, Ireneusz, Klemens Aleksandryjski, Orygenes, Rufin z Akwilei itd.), starając się przede wszystkim nie tyle opisać zachowanie się Chrystusa w otchłani, co odczytać i objaśnić cel Jego zejścia, a nawet umieścić tę prawdę w symbolach wiary ${ }^{7}$. Patrystyczne objaśnienia tych wzmianek są również na ogól, podobnie jak one same, bardzo skąpe i lakoniczne, a wskazywany przez nich cel tego zstąpienia da się sprowadzić, jak zauważył Alois Grillmeier, do trzech: I. Chrystus zstąpił do otchłani, by ogłosić zbawienie przebywającym tam, jak w więzieniu, duszom sprawiedliwych zmarłych oraz ich wskrzesić (np. Hermas, Ireneusz, Klemens Aleksandryjski, Tertulian); II. niektórzy (np. Hipolit, Orygenes) wprowadzając tam Jana Chrzciciela, który i tu poprzedza, zapowiada i przygotowuje przybycie Chrystusa, mającego pouczyć, w jakiś sposób ochrzcić oraz wybawić dusze sprawiedliwych z rąk śmierci i szatana, czyli wyzwolić ludzi Starego Przymierza spod ich władzy; III. Chrystus zstąpił do otchłani, by stoczyć walkę ze śmiercią i hadesem, odnieść nad nimi ostateczne zwycięstwo i uwolnić sprawiedliwych ${ }^{8}$.

$\mathrm{Z}$ czasem jednak zrodziła się kontrowersja o zasięg zbawienia tych zmarłych przebywających w otchłani: czy Chrystus zstępując tam uwolnił wszystkich grzeszników i sprawiedliwych, nawrócił wszystkich grzeszników i niewierzących i udzielił im chrztu, czy też uwolnił tylko tych, którzy przez swe życie na ziemi zasłużyli sobie na zbawienie ${ }^{9}$. Ogół Ojców Kościoła przyjmował tę ostatnią opinię; m.in. św. Jan Chryzostom odrzucał w ogóle pojęcie

\footnotetext{
${ }^{7}$ Por. R.H. Connolly, The Early Syriac Creed, ZNW 7 (1906) 202-223; J.N.D. Kelly, Early Christian Creeds, London 1972, 378-383 (The Descent to Hell); J. Kroll, Zur Geschichte des Spieles von Christi Höllenfahrt, „Vorträge der Bibliothek Warburg (Leipzig)” 7 (1931) 257-301; M. Lochbrunner, Descensus ad inferos. Aspekte und Aporien eines vergessenen Glaubensartikels, MThZ 9 (1993) 161-177; S. Longosz, Struktura Symbolu Apostolskiego, w: Symbol Apostolski w nauczaniu i sztuce Kościoła do Soboru Trydenckiego, red. R. Knapiński, Lublin 1997, 77-98, spec. s. 90-93.

${ }^{8}$ Por. A. Grillmeier, Christ in Christian Tradition. From the Apostolic Age to Chalcedon (451), transl. J.S. Bowden, London 1965, 87; zob. Ad I: Hermas, Pastor. Similitudo IX 16, 5-7; Evangelium Petri 41; Oracula Sibyllina VIII 510-312; Epistula Apostolorum 27 (38); Iraeneus, Adversus hae-

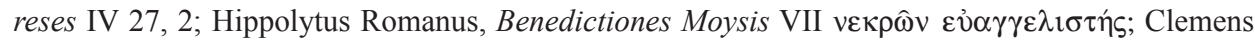
Alexandrinus, Stromata II 9, 44, 1-2; VI 6, 48, 3-6; Origenes, Contra Celsum II 434; zob. Ad II: Hermas, Pastor. Similitudo IX 16, 3 i 5; Epistula Apostolorum 27 (38); Odae Salomonis 42 i 20. Zob. Ad III: Odae Salomonis 17, 9; 42, 11; Testamentum Danielis 5, 11; Acta Thomae 143, 32, 10; Melito Sardensis, Homilia paschalis 68 i 102; Amphilochius Iconiensis, Oratio [V] in diem Sabbati Sancti, SCh 552, 358-368; por. A. Grillmeier, Der Gottessohn im Totenreich. Soteriologische und christologische Motivierung der Descensuslehre in der älteren christlichen Überlieferung, ZKTh 71 (1949) 1-23; H.J. Schulz, Die „Höllenfahrt” als Anastasis, tamże 81 (1959) 1-66; D. Sheerin, St. John the Baptist in the Lower World, VigCh 30 (1976) 2-3.

${ }^{9} \mathrm{Na}$ temat tych kontrowersji zob. L. Caperan, Le problème du salut des infédeles. Essai historique, I, Paris 1912, 51-132; J.W. Dalton, Christ's Proclamation to the Spirits. A Study of 1 Peter 3:18 - 4:6, Analecta Biblica 23, Roma 1965, spec. s. 16-20; J. Galot, La Descente du Christ aux enfers, NRTh 83 (1961) 481-482; Kelly, Early Christian Creeds, s. 380-382; Sheerin, St. John the Baptist in the Lower World, s. 2-3.
} 
nawrócenia i zbawienia po śmierci (co zdawał się przyjmować Klemens Aleksandryjski u tych, którzy nie znając za życia Chrystusa, poznawszy Go w otchłani, uwierzyli w Jego naukę i nawrócili się), podobnie jak na Zachodzie Filastriusz z Brescii (2. poł. IV w.), św. Augustyn († 430), czy idący za nimi papież św. Grzegorz Wielki († 604), który przyjmował że Chrystus ,zstępując do otchłani tych tylko przez łaskę uwolnił, którzy w Niego i że przyjdzie uwierzyli, a w życiu Jego przykazań przestrzegali" ${ }^{10}$. Byli jednak i tacy, m.in. nazywani przez autora Praedestinatus ,adecerbitami” (Adecerbitae - "A $\delta \eta$ $\kappa \varepsilon \rho \beta^{i} \tau \alpha \imath$ ), którzy przyjmowali zbawienie przez Chrystusa wszystkich przebywających w otchłani, co jednak Filastriusz i Augustyn uważali za herezję ${ }^{11}$. Autorzy interesujących nas dramatyzowanych homilii paschalnych problemem tym na ogół się nie zajmowali.

Doktryna o zstapieniu Chrystusa do otchłani głoszona była najczęściej w kierowanych do katechumenów podczas liturgii chrzcielnej w Wielką Sobotę homiliach paschalnych, które pojawiają się już w poł. II w. (np. Melitona z Sardes) ${ }^{12}$, by rozkwitnąć w IV-VI w.; jej autorami byli (m.in. Orygenes, Efrem Syryjczyk, Amfiloch z Ikonium, Augustyn) albo im ją nierzadko przypisywano, niekiedy najwybitniejsi Ojcowie Kościoła. Była to jednak nauka pochodzenia raczej judeochrześcijańskiego, której początkowo należy szukać w środowiskach syryjskich II wieku. Na wyobraźnię chrześcijan odnośnie prawdy zstąpienia Chrystusa do otchłani wpływały ponadto u pochodzących z pogaństwa znane mity o Heraklesie i Orfeuszu, a na wywodzących się z judaizmu późnoantyczna eschatologiczna tradycja żydowska (m.in. Testament Dwunastu patriarchów, Wniebowstapienie Izajasza i pisma z Qumran), które doprowadziły w końcu do przekonania, że zstępując w świat podziemny pokonał On również potęge panujących w nim złych mocy ${ }^{13}$. Były to jednak długo na ogół tylko zwięzłe i lakoniczne opisy zstąpienia, ograniczające się do triumfalnego niekiedy stwierdzenia, że Chrystus zstąpił do otchłani, pokonał śmierć, wziął w niewolę hades oraz wyzwolił przebywających w nim zmarłych. Z czasem jednak, zwłaszcza w okresie V-VII w., pojęcia te - śmierć i hades - zaczęto uosabiać podkreślając, że Chrystus zstępując musiał z nimi stoczyć walkę i zwycięsko je pokonać. Proces ten znalazł swój szerszy i widoczny

${ }^{10}$ Por. Joannes Chrysostomus, In Matthaeum hom. 36, PG 57, 414-417, thum. J. Krystyniacki, ŹMT 18, Kraków 2000, 421-427; Clemens Alexandrinus, Stromata VI 6, 48, 3-6, GCS 52, 456, tłum. J. Niemirska-Pliszczyńska: Klemens Aleksandryjski, Kobierce, II, Warszawa 1994, 139-140; Filastrius Brixensis, Diversarum haereseon liber 125, 1-6, CCL 9, 288; Augustinus, De haeresibus 79, ed. L.G. Müller: The „,De haeresibus” of St. Augustine, Washington 1956, 114; Gregorius Magnus, Epistula VII 15, CCL 140, 465: „Descendens quippe ad inferos solos illos per suam gratiam liberavit, qui eum et venturum esse crediderunt et praecepta eius vivendo tenuerunt".

${ }^{11}$ Por. Praedestinatus 79, PL 53, 614B.

${ }^{12} \mathrm{O}$ homiletyce paschalnej por. H. Gstrein, Unedierte Texte zur Geschichte der byzantinischen Osterpredikt, Wien 1968, 35-84; Grillmeier, Der Gottessohn im Totenreich, s. 1-53 i 184-203.

${ }^{13}$ Por. J. Kroll, Gott und Hölle. Der Mythos vom Descensuskampfe, Leipzig - Berlin 1932, 316-520. 
wyraz w trzech ówczesnych gatunkach literackich - najpierw w powstających wówczas ewangeliach apokryficznych, a następnie w wygłaszanych (z nierzadkim ich wykorzystaniem) popularnych wtedy dramatyzowanych homiliach paschalnych oraz $\mathrm{w}$ hymnografii bizantyńskiej (np. w hymnach przez Romana Melodosa). Wszystkie one obficie czerpały z powyższej tradycji i sposobu prezentowania Chrystusowego zejścia do otchłani jako triumfu nad mocami śmierci i hadesu, połączonego ze wspomnianymi motywami ogłoszenia zbawienia i wyprowadzenia starotestamentalnych sprawiedliwych. Swego rodzaju ,nowością” było ujmowanie tych wątków w rozbudowaną i przemyślaną formę literacką, która - zwłaszcza poprzez elementy dramatyczne, jak partie dialogowe i wartki tok akcji - mocno trafiała do wyobraźni słuchaczy. Bezprecedensowe też było świadome wprowadzenie uosobionej postaci Hadesa, który wraz z Diabłem, jako przeciwnicy Chrystusa, należeli do głównych dramatis personae ${ }^{14}$.

$\mathrm{Na}$ udramatyzowane przedstawienie zstapienia Chrystusa do otchłani w homiliach paschalnych największy bez wątpienia wpływ wywarła apokryficzna Ewangelia Nikodema, ukształtowana w swej ostatecznej obecnej łacińskiej formie, zwłaszcza jej trzecia część (rozdz. 17-27: Descensus), w okresie V-VIII w., a najprawdopodobniej w VI wieku ${ }^{15}$; choć tematyka ta pojawia się już we wschodnich homiliach paschalnych $\mathrm{V}$ w., to nie można udowodnić ich bezpośredniej łączności z tym apokryfem. Obecny tekst tejże ewangelii składa się z trzech dość luźno związanych ze sobą części: I. Opis procesu i męki Jezusa (1-12), II. Dzieje dobrego Łotra, uwięzienie i wyzwolenie Józefa z Arymatei (12-16) oraz szczególnie nas interesujące, słynne III. Zstapienie do otchłani (17-27) ${ }^{16}$. Ta zaś część, zawierająca opis zdarzeń następujących bezpośrednio po śmierci Chrystusa, jest relacją Nikodema, przedstawioną na życzenie Annasza i Kajfasza, zapisaną pod przysięgą na jego życzenie przez wskrzeszonych wcześniej przez Jezusa w otchłani Karinusa i Leucjusza, synów ewangelicznego starca Symeona. Rozpoczyna się od rozmowy znajdujących się w otchłani (hadesie) patriarchów i proroków (Adama, Izajasza, Symeona, Seta) z Janem Chrzcicielem na temat starotestamentalnych proroctw o wcieleniu Syna Bożego i zbawieniu przez Niego ludzkości, sprowokowanej rozbłyskiem niezwykłego światła, zwiastującego zbliżanie się Chrystusa (1719). Potem następuje rozmowa między księciem i wodzem śmierci Szatanem a upersonifikowanym władcą podziemi Hadesem, którego pierwszy nazywa

${ }^{14}$ Por. Skrzyniarz, Hades. Recepcja, s. 57-58.

${ }^{15}$ Por. M. Starowieyski, Wprowadzenie, w: Apokryfy Nowego Testamentu, I 2, Kraków 2003, 634.

${ }^{16}$ Tekst III części Ewangelii Nikodema [CApNT 62] - ed. C. Tischendorf: Evangelium Nicodemi, pars III sive Descensus Christi ad inferos, w: Evangelia apocrypha, Leipzig 1876, repr. Hildesheim 1966, 323-332, lub ed. H.C. Kim, The Gospel of Nicodemus, Toronto 1973, thum. i oprac. M.Starowieyski: Ewangelia Nikodema, cz. III: Zstapienie do otchłani, w: Apokryfy Nowego Testamentu, I 2, wyd. 1, Lublin 1980, 445-451; wyd. 2, Kraków 2003, 653-665; por. Z. Izydorczyk, The Medieval Gospel of Nicodemus: Texts, Intertexts and Contexts in Western Europe, Tempee Ariz 1997. 
„nienasyconym żarłokiem” i z ironią ostrzega, by się przygotował na przybycie tzw. „Syna Bożego", będącego jednak tylko lękającym się śmierci, a nawet ukrzyżowanym człowiekiem, choć za życia dokonał też wielu cudów. Hades jednak w odpowiedzi zaznacza, że choć Przychodzący jest ich wspólnym wrogiem, to jednak większym dla Szatana, który z kolei zachęca swego rozmówcę, by Przybysza schwytał, zatrzymał i uwięził. Hadesowi jednak entuzjazm i pewność Szatana wcale się nie udziela; ogarnia go strach i ma przeczucie klęski, a przypominając sobie Jego wskrzeszenia umarłych, zwłaszcza Łazarza, lęka się, że gdy On się w hadesie zjawi, nikt z umarłych mu w nim nie zostanie (20). W następnym rozdziale dochodzi do kulminacji dramatu: poprzez pojawienie się Chrystusa, nadchodzącego w huku grzmotów i wzywającego władców podziemi Szatana i Hadesa do otwarcia bram, dialog przechodzi w wartką akcję. Szatan wyrzucony przez Hadesa opuszcza go, by stawić czoła Chrystusowi, Hades zaś nakazuje swoim demonom zaryglować bramy, przeciw czemu protestują Dawid i Izajasz, argumentując proroctwami o zmartwychwstaniu bezzasadność tego rodzaju oporu i wzywając do otwarcia bram, do czego dołącza się też apel aniołów, wskutek czego bramy się kruszą i wala, a potężny i zwycięski Pan wkracza do hadesu w ludzkiej postaci i uwalnia wszystkich więźniów. Podczas tej dramatycznej akcji, w ciemnym hadesie, jak zaznacza narrator, pojawia się wielkie światło (21). W kolejnym rozdziale (22) apokryfu akcja się powoli uspokaja: Hades wydawszy okrzyk: „Biada nam, zostaliśmy pokonani”, przyznaje się do klęski i wyznaje swą wiarę w moc Chrystusa, który pochwyciwszy Szatana za czub głowy nakazuje mu zakuć w żelazo jego ręce, nogi i szyję oraz trzymać do powtórnego Jego przyjścia, co ten posłusznie wykonuje, czyniąc z szyderstwem zakutemu i milczącemu Szatanowi litanię wymówek (23), że z jego powodu utracił wszystkich przetrzymywanych od wieków zmarłych; wówczas Chrystus zapewnia go, że w ich miejsce będzie teraz przetrzymywał przez wieki skutego Szatana. Pozostałe rozdziały apokryfu (24-27) opisują wyprowadzanie z otchłani przez Chrystusa sprawiedliwych zmarłych z Adamem na czele i ich wprowadzanie do raju; ci z dziękczynieniem, modlitwą i śpiewem (w czym wyróżniali się Dawid oraz prorocy Habakuk, Micheasz, Henoch i Eliasz oraz dobry Łotr), błogosławieni przez Chrystusa, radośni i szczęśliwi wychodzili, i przez Michała Archanioła wprowadzani byli do raju (25-26), gdzie najpierw spotykaja Henocha, Eliasza i dobrego Łotra.

Drugim apokryfem, który mógł wpływać na rozwijanie i poszerzanie tematu zejścia Chrystusa do otchłani - aczkolwiek w mniejszym zapewne stopniu, bo był krótszy i ogólniejszy - była tzw. Ewangelia Bartlomieja, występująca w wersji łacińskiej także pod nazwą Quaestiones sancti Bartholomaei apostoli (Zapytania świętego Bartłomieja Apostoła), której teologia wskazuje, iż „obecna wersja utworu powstała w czasach Soboru Efeskiego (431), jakkolwiek posiada on z pewnością elementy wcześniejsze i być może powstał 
w III, a może nawet w II wieku"17, choć w zrębie swoim wywodzi się z IV-wiecznego dzieła gnostyckiego, powstałego w środowisku egipskim ${ }^{18}$. Cały utwór składa się z pięciu nierównych pod względem długości scen: w pierwszej, nas tu interesującej, Bartłomiej pyta Chrystusa o Jego śmierć i zstąpienie do otchłani (I 1-9); w drugiej pyta Go o tajemnicę Jego cudownego poczęcia; w trzeciej, bardzo krótkiej, pyta o tajemnicę otchłani (piekła), której apostołowie nie mogą oglądać; w czwartej, najdłuższej, pyta o szatana i jego objawienia oraz o powstanie aniołów, człowieka i szatana; w piątej stawia trzy pytania nie związane z utworem: o najcięższy grzech, o grzech przeciw Duchowi Świętemu i o grzech cudzołóstwa.

Interesujący nas opis zejścia Chrystusa do otchłani, ,prawdopodobnie najstarszy opis tego wydarzenia" ${ }^{19}$, zajmuje, jak widać, w porównaniu z Ewangelia Nikodema, zaledwie kilkanaście zdań (I 9-20), ograniczających się w zasadzie do przytoczenia rozmowy Hadesa z Diabłem Belialem ${ }^{20}$. Charakterystyka obydwóch rozmówców i poruszane przez nich kwestie, są podobne do tych w Ewangelii Nikodema: Hades lęka się Chrystusa przewidując w Jego przyjściu utratę swego panowania nad zmarłymi, Diabeł zaś bagatelizuje tę sytuację i zachęca towarzysza do stawienia Mu oporu. Całość sceny mieści się w odpowiedzi Chrystusa na pytania Bartłomieja, który najpierw Go pyta, gdzie był, gdy zszedł z krzyża, On zaś odpowiada, że zszedł do otchłani, ,,aby wyprowadzić stamtąd Adama i patriarchów" (I 9), a przychodzi z aniołami, by rozwalić żelazne jej zasuwy i bramy. Wtedy dopiero włącza się Hades (Piekło), który zauważa, iż czuje, że zbliża się Najwyższy, któremu on nie jest w stanie się oprzeć, na co reaguje szatan Belial, by się nie lękał i nie ustępował, bo Bóg nie zstępuje nigdy na ziemię (I 14). Chrystus zstępuje niżej dalszych pięćset stopni z aniołami wzywającymi, by otworzono bramy, bo zbliża się Król Chwały, co wywołuje jeszcze większe przerażenie u Hadesa, czującego Bożą potęgę. Belial dodaje mu jednak otuchy i zachęca, by się nie poddawał, ale zaryglował dobrze bramy, bo jest to tylko prorok podobny do Boga, którego trzeba schwytać, związać i dołączyć do zmarłych. Nie przekonany tym jednak przerażony Hades pyta, który to może być prorok podobny do Boga - mąż sprawiedliwości Henoch czy Eliasz mściciel, bo pękając ze strachu czuje, że jest to Bóg; w konsekwencji

${ }^{17}$ M. Starowieyski, Zapytania Bartlomieja. Wprowadzenie, w: Apokryfy Nowego Testamentu, I 2, wyd. 2, s. 756.

${ }^{18}$ Por. A. Wilmart - E. Tisserant, Fragments grecs et latins de l'Évangile de Barthélémy, RB 10 (1913) 161-190, 321-368; U. Moricca, Un nuovo testo dell'Evangelio di Bartolomeo, RB 30 (1921) 481-516; 31 (1922) 20-30 (tekst łaciński); P. Perkins, The Gnostic Dialogue. The Early Church and the Crisis of Gnosticism, New York 1980; A.P.L. Beeston, The „Quaestiones Bartholomae”, JTS 25 (1974) 24-127; J.D. Kaestli, Où en est l'étude de l'Évangile de Barthelémy, RB 95 (1988) 5-33.

${ }^{19}$ Starowieyski, Zapytania Bartłomieja. Wprowadzenie, s. 757.

${ }^{20}$ Por. Evangelium Bartholomaei (CApNT 63) I 9-20, ed. J.D. Kaestli - P. Cherex, Apocryphes 1, Turnhout 1993, 27-142, 254-356 (przekład francuski), tłum. R. Bartnicki, oprac. M. Starowieyski: Zapytania Bartlomieja, w: Apokryfy Nowego Testamentu, I 2, wyd. 2, s. 757-775 (całe), s. 758-759 (I 9-20). 
tego walą się wszystkie bramy podziemi i wkracza Chrystus, który, jak sam opowiada, pochwycił go, zadał mu sto ciosów, związał nierozerwalnymi łańcuchami, wyprowadził wszystkich patriarchów i powrócił na krzyż (I 15-20).

Celowo, stosunkowo dokładnie streściliśmy opisy zejścia Chrystusa do otchłani w tych dwóch apokryficznych ewangeliach, by później móc łatwiej zauważyć, ile z nich (czy z innych krążących wówczas, a zaginionych podobnych apokryfów), myśli, sytuacji, a nawet wyrażeń, mogli zaczerpnąc kaznodzieje przy prezentowaniu tego wydarzenia w swoich dramatyzowanych homiliach paschalnych.

Otóż wczesnochrześcijańskim kaznodzieją, który chyba najbardziej poszerzył, rozbudował i udramatyzował w swoich homiliach scenę zstąpienia Chrystusa do otchłani (=,,do piekieł”) poprzez wprowadzenie w nich obszernych i pełnych napięcia dialogów prowadzonych przez związane z nimi postacie, był nieznany nam bliżej, tajemniczy, żyjący najprawdopodobniej w 2 . poł. V, a może nawet VI w. Euzebiusz z Aleksandrii, autor 22 homilii ${ }^{21}$, wśród których współcześni badacze wyodrębniają „euzebiański cykl” zstapienia Chrystusa do otchłani ${ }^{22}$. Wspomniany wyżej zbiór jego homilii o różnorodnej, W większości katechetyczno-liturgicznej i moralnej treści, głoszonych bardzo prostym, ludowym, na wzór diatryby językiem, z licznymi pytaniami, zwrotami i apelami, kierowanymi bezpośrednio w drugiej osobie do słuchacza, a $\mathrm{w}$ homiliach paschalnych tworzonymi udramatyzowanymi dialogami postaci biblijnych, mogły się zapewne słuchaczom podobać, a nawet być wykorzystywane w liturgii. Homiletyczny ,euzebiański cykl” zstapienia Chrystusa do otchłani, będący bez watpienia, jak to wykazują badacze ${ }^{23}$, retoryczną amplifikacją treści i ogólnej struktury apokryficznego opisu zstąpienia Chrystusa do piekieł w III części Ewangelii Nikodema, gdzie po rozmowie Jana Chrzciciela z prorokami i patriarchami następuje poprzedzająca przybycie Chrystusa nerwowa wymiana zdań między przestraszonym Diabłem i Hadesem, zawiera w sobie 5 mów tajemniczego Biskupa: pierwsze dwie (XII. Na słowa: „Ty jesteś, który miat przyjść, czy innego czekamy” oraz XIII. O zstapieniu Jana do otchtani i przebywajacych tam zmartych) stanowią swego rodzaju wprowadzenie do tematu, opowiadając o wzmiankowanym przez Ewangelie

${ }^{21}$ Por. CPG 5510-5531; Vita Eusebii Alexandrini [CPG 5533; BHG 635], PG 86, 297-309; zob. Lafontaine, Les homélies d'Eusèbe d'Alexandrie, passim; L.S.B. MacCoull, Who was Eusebius of Alexandria?, „Byzantinoslavica” 60 (1999) 9-18; S. Longosz, Euzebiusz z Aleksandrii i jego homilie (artykuł zostanie przygotowany do publikacji w jednym z następnych tomów „Vox Patrum”).

${ }^{22}$ Zawiera on 5 jego homilii: In illud:,, Tu es, qui venturus es, an alium exspectamus" [CPG 5521], XIII. De adventu Joannis in infernum et ibi inclusis [CPG 5522], XIV. De proditione Judae [CPG 5523], XVII. De Christi passione [CPG 5526], XV. In Diabolum et Orcum (= Hadem) [CPG 5524].

${ }^{23}$ Por. J.A. McCulloch, The Harrowing of Hell. A Comparative Study of an Early Christian Doctrine, Edinburgh 1930, 174-191; Sheerin, St. John the Baptist in the Lower World, s. 16-20; G. Lafontaine, La version arménienne du sermon d'Eusebe d'Alexandrie „, Sur la venue de Jean aux enfers”, „Le Muséon” 91 (1978) 88-89. 
Nikodema wcześniejszym zstapieniu Jana Chrzciciela do otchłani, by zapowiedzieć przybycie Chrystusa, na co odpowiadają przebywający tam zmarli patriarchowie i prorocy; pozostałe trzy mowy tego cyklu (XIV. O zdradzie Judasza, XVII. O męce Chrystusa, XV. O Diable i Hadesie) prezentują już sam temat, przeważnie $\mathrm{w}$ formie udramatyzowanych dialogów związanych z nimi postaci, głównie upersonifikowanych Hadesa (= Orkusa) i Diabła, oczekujących z przerażeniem przybycia niespodziewanego Gościa i wynikających $\mathrm{z}$ tego faktu tragicznych dla nich przewidywanych konsekwencji. Homilie te ze względu na swą prostotę i dramatyczny charakter od początku cieszyły się wielką popularnością, były tłumaczone na lokalne języki codziennego użytku (najczęściej na syryjski i armeński), a niektóre z nich wykorzystywane w liturgii Wielkiego Tygodnia (być może z tą myślą były też pisane). Dzięki tym licznym przekładom na języki orientalne, a nawet słowiańskie, ich oddziaływanie wykraczało daleko poza środowisko greckojęzyczne, i do końca I tysiąclecia objęło niemal cały chrześcijański Wschód. Jako uzupełnienie homiletycznego euzebiańskiego cyklu o zstąpieniu Chrystusa do otchłani dołączamy tu znaną (choćby z Liturgii Godzin), przypisywaną różnym autorom starożytną Homilie o pogrzebaniu Bożego Ciała i zstapieniu do otchtani $i^{24}$. Wszystkie te homilie razem wzięte, zdaniem G. La Piany ${ }^{25}$, zdają tworzyć pewnego rodzaju pierwotny dramat chrześcijański w trzech aktach: A. Zstapienie Jana do otchłani i jego dialog z przebywającymi tam zmarłymi prorokami, B. Zdrada Judasza i męka Chrystusa oraz przerażenie władców podziemi Szatana i Hadesa (= Orkusa) lękających się Jego odwiedzin i wynikających z tego konsekwencji, C. Zstąpienie Chrystusa do otchłani oraz uwolnienie przebywających tam proroków i patriarchów.

\section{A. Zstąpienie Jana do otchłani}

$\mathrm{Na}$ treść i strukturę euzebiańskich homilii o zstąpieniu Chrystusa do otchłani, w tym również obecności w nich Jana Chrzciciela, o czym w tym kontekście milczą przekazy biblijne, niemały wpływ, jak zaznaczaliśmy, miała apokryficzna Ewangelia Nikodema. Warto tu jednak przypomnieć, że takie wyprzedzające zejście zmarłego Jana do otchłani, mającego zapowiedzieć i przygotować tam przybycie Chrystusa, przyjmowało już wcześniej kilkunastu Ojców Kościoła z ogólnym uzasadnieniem, że jak ongiś prorocy na ziemi przygotowywali ludzi w historii zbawienia na przyjście Mesjasza, tak teraz i on jako ostatni prorok winien przygotować sprawiedliwych zmarłych przebywających w otchłani na przyjście i uwolnienie ich przez Chrystusa. Takie wypowiedzi, w znakomitej większości bardzo ogólne, spotykamy w pismach autorów wczesnochrześcijańskich już od III wieku. Jako pierwszy uczynił to

${ }^{24}$ Por. Homilia in divini Corporis sepulturam et de Christi adventu in infernum [CPG 3768], PG 43, 439-463.

${ }^{25}$ Por. La Piana, Le rappresentazioni sacre, s. 80. 
kilkakrotnie, aczkolwiek bardzo ogólnie, główny przedstawiciel Szkoły Aleksandryjskiej Orygenes († 254), który stwierdzał, że Jan jak za życia w wielu sprawach był poprzednikiem Chrystusa, tak i po śmierci wyprzedził Go w otchłani, aby i tam oczekującym sprawiedliwym zapowiedzieć Jego przyjście i uwolnienie ich z rąk śmierci ${ }^{26}$. Podobnie, prawie w tym samym czasie, w Rzymie uczył umęczony za Chrystusa prezbiter Hipolit (†235 $)^{27}$. W IV w. chyba najciekawiej wyraził tę prawdę ok. 348 r. w swoich katechezach św. Cyryl Jerozolimski (†386), ujmując w kilku zdaniach, jak w soczewce, w formie pytań i odpowiedzi prawie to wszystko, co Euzebiusz wyraził w swoich dramatyzowanych homiliach: o przebywających w otchłani oczekujących od wieków prorokach, o lęku i rozterkach jego strażników - śmierci, szatana i Hadesa przerażonych wizją zstapienia do nich Chrystusa, oraz o Jego tam przybyciu celem uwolnienia sprawiedliwych ${ }^{28}$. Oprócz niego, ale również raczej ogólnie,

${ }^{26}$ Por. Origenes, In I Regum hom. [CPG 1423] 28, 3-25 GCS 6, 289, 27-29 i 290, 17-22 lub PG 12, 1021B i 1024A: „Chrystus zstapił do piekieł, a przed nim prorocy, którzy zapowiedzieli Jego przybycie [...]. I Jan, od którego wśród narodzonych z kobiet nie było większego, jak zaświadczył sam Chrystus (Mt 11, 11; Łk 7, 28), zstąpił do piekieł zapowiadając Pana, aby zapowiedzieć, że On zstapi”; In Lucam hom. 4, 5, GCS 49 27, 19 - 28, 4, lub SCh 87, 134, thum. S. Kalinkowski, PSP 36, 42: „Jan zaś był poprzednikiem Pana, i umarł przed Nim, aby zstąpiwszy do piekieł, również i tam zapowiedzieć Jego przyjście"; In Joannem II 37, 224, SCh 120, 360-362, thum. S. Kalinkowski, PSP 28, 145: „Czy Jan zawsze był świadkiem i poprzednikiem Jezusa? Poprzedził Jego narodzenie i zmarł niedługo przed śmiercią Syna Bożego, aby przebywając przed Chrystusem nie tylko wśród tych, którzy znajdują się przy życiu, ale i wśród tych, którzy oczekują na uwolnienie od śmierci za sprawą Chrystusa, wszędzie «przygotować Panu lud doskonały» (Łk 1, 17)”; zob. Sheerin, St. John the Baptist in the Lower World, s. 4-7.

${ }^{27}$ Por. Hippolytus, De Christo et Antichristo 45, GCS 1, 29, $5-8$ lub PG 10, 725, tłum. S. Kalinkowski, ŹMT 17, Kraków 2000, 131: „Następnie pojawił się jako nauczyciel na pustyni, głosząc ludowi «chrzest nawrócenia» (Mk 1, 4); zapowiadał w ten sposób zbawienie ludom mieszkającym na pustyni świata. Jeszcze później nad Jordanem osobiście wskazał na Zbawiciela i stwierdził: «Oto Baranek Boży, który gładzi grzech świata» $(J$ 1, 29). On wreszcie zamordowany przez Heroda poprzedził Chrystusa głosząc dobrą nowinę tym, którzy przebywali w otchłani; zatem tam również był Jego Zwiastunem, zapowiadając, że i tam przyjdzie Zbawiciel, który wykupi dusze świętych z ręki śmierci”.

${ }^{28}$ Por. Cyrillus Hierosolymitanus, Catechesis 14, 19, PG 33, 848-849, tłum. W. Kania, BOK 14, 222: „Sam [Chrystus] zstapił do otchłani, lecz w licznym orszaku z niej wyszedł. Zstapił w śmierć, lecz wskrzesił wiele ciał zmarłych. Przestraszyła się śmierć, jak zobaczyła, gdy nowy przybysz zjawił się w otchłani, nie związany więzami śmierci. Strażnicy otchłani, czemu przestraszyliście się na Jego widok? Dlaczego ogarnęła was wielka trwoga? Śmierć zbiegła, zdradzając w ten sposób swą bojaźń. Zjawili się święci prorocy, prawodawca Mojżesz, Abraham, Izaak i Jakub, Dawid i Samuel, Izajasz i Jan Chrzciciel, który świadczył: «Ty jesteś, który miałeś przyjść, czy na innego mamy czekać?» (Mt 11, 3). Odzyskali wolność wszyscy przez śmierć pochłonięci sprawiedliwi. Wypadało bowiem, aby Król wybawił wybornych heroldów, którzy Go przepowiedzieli. Każdy z tych sprawiedliwych mówił wtedy: «Gdzież jest, o śmierci, twe zwycięstwo? Gdzież jest, otchłani, oścień twój» (1Kor 15, 55) Uwolnił nas Zwycięzca”; Catechesis 4, 11, PG 33, 469B, BOK 14, 65: „W otchłani był również Dawid i Samuel, i wszyscy prorocy, również Jan, który przez swych posłów zapytał: «Czy Ty jesteś tym, który ma przyjść, czy na innego mamy czekać?» (Mt 11,3). Czy nie chciałbyś, aby zstąpił i uwolnił takich mężów?" 
wypowiadali się w tym okresie na ten temat: w Kapadocji św. Grzegorz z Nazjanzu $(† 394)^{29}$, w czasach Euzebiusza Sofroniusz z Jerozolimy (VI/VII w.) $)^{30}$, a na Zachodzie w Italii: w Mediolanie św. Ambroży $(† 397)^{31}$, w Akwilei Rufin wprowadzający prawdę o zstąpieniu Chrystusa nawet do Symbolu Apostolskiego $^{32}$, w Rzymie św. Hieronim $(† 419)^{33}$, a w Turynie biskup tego miasta

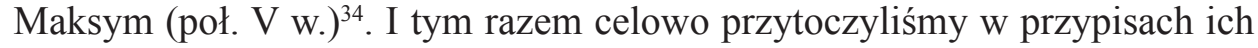
wypowiedzi in extenso, by łatwiej można było zauważyć amplifikację tego szczegółu w euzebiańskich homiliach o zstappieniu również Jana do otchłani, z których tu dwie prezentujemy.

1. Homilia na stowa: „Ty jesteś Tym, który ma przyjść, czy na innego czekamy” - XII mowa Pseudo-Euzebiusza Aleksandryjskiego, komentującego zapisane w Ewangelii św. Mateusza $(11,3)$ pytanie uwięzionego przez Heroda Jana Chrzciciela, postawione Chrystusowi przez posłanych jego uczniów ${ }^{35}$. Kaznodzieja objaśnia obszernie w 3/4 mowy okoliczności jego postawienia

${ }^{29}$ Por. Gregorius Nazianzenus, Oratio 43, 75, PG 36, 597A, thum. anonimowe w: Św. Grzegorz z Nazjanzu, Mowy wybrane, Warszawa 1967, 520: „Kto był prekursorem Jezusa? Jan, jako głos Słowa i jako pochodnia światłości [...], który wyprzedził Go do piekieł, posłany tam przez szaleństwo Heroda, aby i tam ogłosił przybywającego".

${ }^{30}$ Por. Sophronius, Encomium in S. Joannem Praecursorem 3, PG 87, 3325C: „O szlachetne odcięcie twojej czcigodnej głowy, przez którą ustanowiony zostałeś podwójnym poprzednikiem Zbawiciela; nie tylko bowiem na ziemi go wyprzedziłeś, ale i do piekieł zstapiłeś jako poprzednik tych, którzy tam czekali i przebywali, jak to na ziemi przepowiadałeś im zbawcze odkupienie".

${ }^{31}$ Por. Ambrosius, Expositio Evangelii secundum Lucam I 38, CCL 14, 25, tłum. W. Szołdrski, PSP 16, 43: „Święty Jan będzie szedł przed obliczem Pana, gdyż jako zwiastun się urodził i jako zwiastun umarł (qui praenuntius natus et praenuntius mortuus est)".

${ }^{32}$ Por. Rufinus, Expositio Symboli 26, CCL 20, 161: „Tu es qui venturus es (in infernum sine dubio) an alium exspectamus?".

${ }^{33}$ Por. Hieronymus, In Matthaeum 11, 3, PL 26, 69-70, thum. J. Korczak, ŹMT 46, 64: „«Ty jesteś tym, który ma przyjść, czy też innego mamy oczekiwać» (Mt 11,3). Nie powiedział: «Ty jesteś tym, który przyszedł», lecz: «Ty jesteś tym, który ma przyjść», a sens jest taki: :«poleć mi, bo już mam zstapić do podziemi, czy mam głosić Ciebie i zmarłym, ja, który ogłaszałem Cię żywym (Manda mihi, quia ad inferna descensurus sum, utrum te et infernis debeam nuntiare qui nuntiavi superis), czy też nie przystoi Synowi Bożemu, by zaznał śmierci, i kogo innego zamierzasz posłać do (realizacji) tych tajemnic»”; Epistula 121, 1, tłum. J. Czuj, ŹMT 63, Kraków 2011, 82-83: „Słowa jego [...] mogą mieć również takie znaczenie: Wiem, że Ty jesteś tym, który przyszedł gładzić grzechy świata, ale ponieważ mam zstąpić do otchłani, pytam także o to, czy i ty tam zstąpisz, czy bezbożnością jest sądzić tak o Synu Bożym, i czy może kogoś innego poślesz. Pragnę wiedzieć, czy tak, jak głosiłem Cię ludziom na ziemi, będę Cię głosił także w otchłani, jeśli tam zstąpisz. Ty bowiem przyszedłeś usuwać niewolę i uwolnić zakutych w więzy”.

${ }^{34}$ Por. Maximus Turonensis, Sermo 61 (In natalem S. Joannis Baptistae), PL 57, 655B: „Uprzedził go w urodzeniu, przepowiadaniu, chrzczeniu i umieraniu, a wreszcie i w zstapieniu do piekieł (Praevenit eum nascendo, praedicando, baptizando, moriendo, postremo et ad inferos descendendo)".

${ }^{35}$ Ps-Eusebius Alexandrinus, Homilia [XII] in illud: ,, Tu es qui venturus es, an alium exspectamus?" [CPG 5521], PG 86, 380-384, spec. 381C-384B, por. Sheerin, St.John the Baptist in the Lower World, s. 17-18. 
oraz różne jego interpretacje, m.in. że Jan nie znał Chrystusa i powątpiewał w Jego bóstwo, co zdecydowanie odrzuca, wykazując jego niedorzeczność. W końcówce mowy, którą niżej prezentujemy, nadaje temu pytaniu znany również wczesnochrześcijańskim egzegetom (m.in. św. Hieronimowi) sens eschatologiczny, odnosząc go do Chrystusa zstępującego do otchłani, w czym uprzedza go i przygotowuje Jego przyjście Jan Chrzciciel. Przytoczony niżej fragment mowy nie ma wprawdzie większego charakteru dramatycznego, ale uważany jest za wprowadzenie do następnej homilii, poświęconej w całości zejściu Jana do otchłani, która takowy charakter posiada:

„Posłuchaj, co Ewangelia opowiedziała o tym, kiedy Herod uwięził Jana z powodu cudzołożącej Herodiady, żony jego brata Filipa. Jan [uwięziony] świadom swego losu i rozumiejąc, że wkrótce przejdzie do otchłani, wysłał [kogoś] do Pana z zapytaniem: «Czy to Ty jesteś Tym, który ma przyjść, czy też na innego czekamy»? Oto - mówi - Panie, zbliża się godzina mojej śmierci; czuję, jak złowieszcza dla mnie jest urodzinowa uczta Heroda. Przewiduje, jaki zasób sztuczek tanecznych przygotowała ze względu na mnie Herodiada; przeczuwam, że pijatyka i dziewczyna pozbawią mnie głowy; doszedłem już do kresu mego życia, wypełnił się już jego cel; przechodzę już do moich ojców, zmierzając do tych, których szatan przetrzymuje zamkniętych w hadesie. A jeśli wówczas oni mnie zapyta ją: «Kto przyjdzie i uwolni nas»?, co im mam odpowiedzieć? Powiedz mi więc prawdę, Panie. Czy to Ty jesteś Tym, który ma przyjść, czy na innego mamy czekać»? Uczniowie zaś Jana przystępując donieśli Mu o tym, Pan natomiast odpowiadając im rzekł: «Oznajmijcie Janowi to, co słyszycie i co widzicie: niewidomi widzą, trędowaci doznają oczyszczenia, ubogim głosi się Ewangelię, a umarli zmartwychwstają» (Mt $11,4)$. Ty, choć sam jesteś biedny, zapowiedz tym, którzy są w hadesie zmartwychwstanie, że zmartwychwstaną. To bowiem oznaczają słowa: «Czy to Ty jesteś Tym, który ma przyjść, czy też na innego mamy czekać»? Z tej odpowiedzi Pana [Jego] Poprzednik zrozumiał, że tych, którzy są w hadesie Zbawiciel uwolni od śmierci. Naprawdę bowiem wypadało, żeby ci w hadesie skorzystali z Jego miłosierdzia. Przed przyjściem bowiem Pana wszyscy przetrzymywani byli w hadesie: był tam obdarzony potężnym głosem Izajasz, był tam żyjący według Bożego serca Dawid, był tam Samuel, Daniel, Ezechiel i pozostali prorocy. Wypadało zatem Panu zstapić do hadesu i ich uwolnić, aby wszyscy ci na ziemi, ci w niebie i ci w hadesie uzyskali od Niego zbawienie i uwielbiali Go, aby wypełniło się to, co zostało powiedziane przez św. Pawła, «aby na imię Jezusa Chrystusa zginało się każde kolano, istot niebieskich, ziemskich i podziemnych, i aby każdy język wyznawał, że Pan Jezus Chrystus jest Panem ku chwale Boga Ojca» (Flp 2, 11-12) na wieki. Amen" (381C i 384A-B).

Nietrudno zauważyć, iż nie jest to zwykłe, zapowiadające kolejną homilię wprowadzenie, ale w swoisty, retoryczny sposób, udramatyzowana introdukcja. Kaznodzieja wnika w niej w głębię duszy uwięzionego Proroka i ukazuje 
wewnętrzną jej stronę: uświadamia on sobie, że z tego więzienia wskutek działań upomnianej Herodiady już nie wyjdzie, zbliża się kres jego życia i odejścia do otchłani, gdzie się spotka z przebywającymi tam przodkami, którzy będą go zapewne pytać, kto ich stamtąd uwolni. Kaznodzieja do komentowanego ewangelicznego pytania, po ukazaniu wnętrza duszy oczekującego na śmierć Więźnia, dołącza więc wyimaginowane dramatyczne drugie pytanie, na które też daje tego samego rodzaju odpowiedź Chrystusa, polecającego mu zapewnić oczekujących tam zmarłych proroków i sprawiedliwych, że zmartwychwstana, kim zaś On jest, dowodzą Jego czyny. Nie brak więc i w tym niedługim zakończeniu homilii pewnej dramaturgii, która zapewne wyciszyła i zainteresowała słuchaczy oraz pobudziła do refleksji.

\section{Homilia o zstapieniu Jana Chrzciciela do otchtani i o przebywających} tam prorokach - długo przypisywana Janowi Chryzostomowi, potem Euzebiuszowi z Emezy (†359), a ostatnio uznana za XIII mowę Euzebiusza Aleksandryjskiego ${ }^{36}$. Kaznodzieja po krótkim wspomnieniu więzienia i dokonanej w nim egzekucji na Janie Chrzcicielu przechodzi w niej do opisu mrocznej otchłani, gdzie więzieni przez Hadesa patriarchowie oczekują na uwolnienie. Gdy nagle pojawia się wśród nich oświetlony żywym światłem Jan Chrzciciel, wszyscy zbiegają się do niego krzycząc:

„Pan zapewne nadchodzi! Jakaż tu panuje beznadzieja, która nas ogarnia. Jeśli jednak rzeczywiście On nadchodzi i wybawi nas z tej beznadziei, to znaczy, iż spełniły się wypowiedziane o Nim proroctwa" (513A).

Tymczasem Jan przybywszy opowiada im o sobie i o swojej misji oraz zachęca zebranych proroków, by teraz powtórzyli swoje proroctwa o mającym przyjść Chrystusie:

„Proszę was, opowiedzcie, co każdy z was przepowiadał kiedyś o Panu, aby słysząc to przebywający w otchłani nabrali otuchy" (513A).

W odpowiedzi na tę propozycję prorocy począwszy od króla Dawida i Izajasza jeden po drugim defiluja przed Janem Chrzcicielem i wypowiadają jedno zdanie ze swych proroctw, odnoszących się bezpośrednio do Chrystusa:

„Odpowiadając na to najpierw prorok Dawid rzekł: «Ja wiedziałem, że On przyjdzie z niebios i przepowiedziałem: «Zstapi jak deszcz na trawe, jak kropla spadająca na ziemię, i jak deszcz spadając na wełnę nie wywoła hałasu» (Ps 71, 6). Izajasz zaś powiedział: «Ja wiedziałem, że narodzi się z Dziewicy

${ }^{36}$ Ps-Eusebius Alexandrinus, Homilia [XIII] de adventu Joannis in infernum et de ibi inclusis [CPG 5522], PG 86, 509-525; por. La Piana, Le rappresentazioni sacre, s. 90-91; Lafontaine, La version arménienne du sermon d'Eusebe d'Alexandrie ,Sur la venue de Jean aux enfers”, s. 87104 (tekst armeński + przekład łaciński); Sheerin, St.John the Baptist in the Lower World, s. 17-18; S. Der Nersessian, An Armenian Version of the Homilies on the Harrowing of Hell, DOP 8 (1954) 203-224; Skrzyniarz, Hades. Recepcja, s. 61-62. 
i przepowiedziałem: Oto Panna pocznie i porodzi Syna i nazwą go imieniem Emmanuel» (Iz 7, 14). Odezwał się kolejny prorok: «Ja zaś wiedziałem, że ma się narodzić w Betlejem i przepowiedziałem: A ty Betlejem, ziemio Judy, wcale nie jesteś najmniejsze wśród książąt Judy, bo z ciebie wyjdzie ten, który będzie prowadził mój lud Izrael» (Mich 5, 2)" (513B).

W ten sposób wypowiadali się kolejni prorocy: Ozeasz, Jeremiasz, Zachariasz oraz występujący powtórnie Dawid, Izajasz i inni przepowiadając ucieczkę Jezusa do Egiptu, różne Jego cuda, zdradę Judasza i ostateczny tryumf Chrystusa. Do tej sceny, jak i do wypowiedzi proroków, kaznodzieja nie dołączał tym razem żadnego swego komentarza. Obserwujący powyższe wypowiedzi i zachowanie się proroków gospodarz otchłani Hades, zaniepokojony ich ewentualnymi konsekwencjami, rozpoczyna długi dialog ze stojącym obok szatanem:

Hades: „O kim mówią ci zarozumialcy? Z czyjego powodu plotą te głupstwa? Któż jest tym przybyszem, że aż tak ich pocieszył?”

Szatan: „Nie bój się ani nie lękaj z powodu ich słów. Tym bowiem, co miał nadejść, jest Jan Chrzciciel. Jest on niewątpliwie odważny, a kiedy jeszcze żył na ziemi, wyświadczył ludziom wiele dobrodziejstw; dał też świadectwo o tym człowieku, o którym teraz im opowiadał, wiele też spraw im wyjaśnił, ale mnie trochę zasmucił. Ogłosił bowiem publicznie, że to jest Ten, który ma uwolnić Izraela. Ja natomiast udałem się do Herodiady, pięknej i oddanej mi kobiety, współtwórczyni wielu moich czynów, oraz nakłoniłem przez nią króla, by podczas uczty ściął głowę Jana i podał ją na półmisku córce, by się nią bawiła jak jabłkiem. Ten zaś, o którym mówiono, że ma odkupić świat, nie potrafił go wyzwolić, gdy natomiast usłyszał o śmierci Jana, w obawie by Herod i jego samego nie zabił, uciekł do Galilei. Wówczas przekonałem się, że jest On zwykłym, śmiertelnym, bojącym się również śmierci człowiekiem i przestałem się niepokoić z jego powodu. Żeby jednak powiedzieć ci prawdę, to początkowo bardzo się martwiłem, a nawet przestraszyłem, żeby i nas nie uczynił swymi niewolnikami?"

Hades: „Uważaj, bracie, byśmy szukając wielkiego poklasku, nie stracili przypadkiem wszystkiego. Nikt bowiem nie jest naszym przyjacielem, a wręcz przeciwnie, wszyscy są naszymi wrogami, i jeśli przytrafiłoby się nam coś złego, nasz ból byłby nieutulony, a smutek niewypowiedziany. Czy sądzisz, że ci prorocy z przyjemnością zgadzają się na to, by ich ciała znajdowały się w tym podziemiu? O tym właśnie mówią, lecz jeśli stąd odejdą, to słusznie nas wyśmieją. A mówię to o tych, nad którymi nie ciąży żadna kara. Jeśliby zaś był tu tłum skazańców i grzeszników, to oni właśnie, mogliby wyśmiać naszą słabość, a cały świat przypisałby nam znamiona nieudolności. Bacz więc pilnie, byśmy nie zostali wykpieni, ci bowiem bardzo się cieszą słuchając takich słów o Nim". 
Szatan: „Mówiłem ci już, byś się nie denerwował ich wypowiedziami. Ja bowiem wiem, kim On jest i nie boję się Go. Tym człowiekiem jest Jezus, który je, pije i śpi, Jego matka nazywa się Maria, a Jego ojciec zajmuje się ciesielstwem; wywodzą się z Nazaretu. Kiedy Jezus się urodził, Herod szukał Go, bo chciał go zgładzić, rodzice jednak zabrali go i uciekli do Egiptu. I chociaż wówczas wymknął się On z moich rąk, to teraz w nie wpadł, i teraz ci Go oddam; przekażę Go w ręce Żydów oraz podburzę ich, a oni wydadzą go trybunałowi, ukrzyżują go i zetrą o nim pamięć na ziemi. Doprowadzę Go w twoje ręce, a ci tutaj przebywający bardzo się z tego zasmucą. Wzmocnij tylko starannie bramy i nie bój się ich słów, bo oni chcą cię przestraszyć" (518 i 520).

Po tej wypowiedzi szatan udaje się, jak komentuje kaznodzieja, do Żydów, by zrealizować swój plan; na tym homilia się kończy i można by ją traktować z poprzednią jako pierwszą scenę dramatu.

\section{B. Zdrada Judasza, pojmanie Chrystusa oraz popłoch władców podziemi}

3. Homilia o zdradzie Judasza ${ }^{37} \mathrm{w}$ ostatnich dwóch stuleciach jej tekst grecki, poświadczony w 17 rękopisach, przypisywany był przez wydawców różnym wczesnochrześcijańskim autorom: Euzebiuszowi z Emezy (Augusti, 1829; Migne, 1860), Euzebiuszowi Aleksandryjskiemu (Mai, 1843), Janowi Chryzostomowi (Hipolit, 1925), Efremowi Syryjczykowi (według kodeksów arabskich poświadczających tradycję syryjską m.in. Borgia arabe, Sbath 38), a nawet Sewerianowi z Gabali (Zellinger, 1926) ${ }^{38}$, niekiedy dołaczany do Mowy o Diable i Hadesie, a ostatnio uznany za XIV homilię Euzebiusza Aleksandryjskiego. Kaznodzieja opowiada w niej najpierw, jak szatan zachęcał $\dot{Z} y-$ dów do prześladowania Jezusa, widząc jednak, że ta sprawa posuwa się zbyt

${ }^{37}$ Ps-Eusebius Alexandrinus, Homilia [XIV] de proditione Judae [CPG 5523], PG 86, 525-536; La Piana, Le rappresentazioni sacre, s. 91-93; G. Lafontaine, La version arménienne du sermon d'Eusebe d'Alexandrie „Sur la trahison de Judas”, „Le Muséon” 91 (1978) 335-353; J.M. Sauget, La version arabe de l'homélie „Sur la trahison de Judas” d'Eusébe d'Alexandrie, „Le Muséon” 92 (1979) 5-23.

${ }^{38}$ Przypisywana Euzebiuszowi z Emezy por. J.C.G. Augusti, Eusebii Emeseni quae supersunt opuscula graeca ad fidem codicum Vindobonensium et editionum diligenter expressa, Elberfeld 1829, 10-14; J.P. Migne, PG 86, Paris 1860, 525-536; Euzebiuszowi Aleksandryjskiemu por. J.A. Mai, Spicilegium Romanum, vol. 9, Roma 1843, 693-696; Janowi Chryzostomowi por. Archimandryta Hipolit w Jerozolimskim Greckim Patriarchacie Ortodoksyjnym por. Hippolyte,

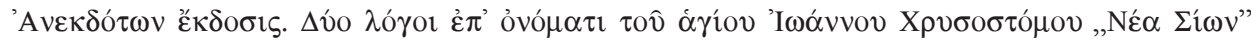
20 (1925) 752-755; Sewerianowi z Gabali por. J. Zellinger, Studien zu Severian von Gabala, Münsterische Beiträge zur Theologie 8, Münster 1926, 142-146. Na podstawie jakich kodeksów i rękopisów je powyższym autorom przypisywano zob. Lafontaine, La version arménienne du sermon d'Eusebe d'Alexandrie , Sur la trahison de Judas”, s. 335-337; J.A. de Aldama, Repertorium pseudochrysostomicum, Paris 1965, s. 25, n. 64, s. 48-49, n. 126; Sauget, La version arabe de l'homélie „Sur la trahison de Judas”, s. 6-8. 
powoli, sam wszedł w duszę Judasza i przekonał go do zdrady. Mówca opisuje dalej przyjście Jezusa do Betanii i ucztę, na którą Go tam zaproszono, oraz podczas której przyszła pokutująca Maria Magdalena, umyła i namaściła $\mathrm{Mu}$ nogi drogocennymi olejkami. Wówczas podniósł się oburzony Judasz i rzekł: „Po co to marnowanie olejku? Przecież można było ten olejek sprzedać drożej niż za trzysta denarów i rozdać ubogim" (Mk 14, 4-5). Gdy Jezus na to nic nie odpowiedział, zdaje się wkraczać chór, który surowym i upominającym głosem występuje przeciw tej obłudzie:

„Nie, Judaszu, tobie nie chodzi o ubogich, ale żądny jesteś tych trzystu denarów, bo chciwość opanowała twe serce. Obłudniku, planujesz wkrótce zabić Pana i Twórcę wszelkiego olejku za trzydzieści srebrników" (528B).

Judasz jednak odchodzi i udaje się do żydowskich kapłanów z propozycją: „Co mi chcecie dać, a ja wam go wydam” (Mt 26, 15). Chór natomiast, który krok po kroku zdaje się śledzić akcję zdrajcy, ponownie rozpoczyna śpiew w nadziei, iż wstrzyma jego działania:

„Powiedz mi, Judaszu, co chcesz otrzymać? [...]. Pytam, cię, Judaszu, powiedz, dlaczego Go zdradzasz? Czy cię stawiał poza swymi pozostałymi uczniami? Czy im przekazał coś, czego tobie nie dał? Czy cię nie uczynił uczestnikiem całej łaski, że go teraz zdradzasz? [...]. Wolałeś, nieszczęśliwcze, przyjąc trzydzieści srebrników i stracić swoją duszę? Siedziałeś przy jego stole, a twoja ręka brała wspólny chleb; Judaszu, dlaczego to uczyniłeś i Pana swego obraziłeś? Stałeś się przyjacielem szatana, a Pana swego zdradziłeś! Chociaż źle postępowałeś, On cię jak siebie samego kochał i do stołu dopuścił, a ty jakiegoż przestępstwa się dopuszczasz? [...]. Biada ci, Judaszu, ponieważ wykorzystując przyjaźń Pana, ujęty głupio żądzą pieniędzy, postanowiłeś stać się nieszczęśnikiem i zdrajcą" (529 i 532).

Judasz jednak pozostaje nieczuły na te wołania chóru, bierze od faryzeuszów pieniądze i sprzedaje Jezusa. Chór zaś śpiewa nadal jeszcze bardziej rozpaczliwym głosem:

„Judaszu, z powodu tych srebrników przybrałeś na siebie przekleństwo jak jakąś szatę. $Z$ powodu tych srebrników straciłeś wiele dóbr, a ściagnąłeś na siebie brzemię zła, stałeś się wygnańcem raju i dziedzicem piekła. Z powodu tych srebrników stałeś się wrogiem dla milionów i tysięcy legionów anielskich, a przyjacielem tylko jednego - oczywiście szatana. Z powodu tych srebrników zostałeś wyrzucony z chóru apostołów, a zaliczony do demonów: zostałeś strącony do piekieł daleko od tronu twego Pana. Z powodu tych srebrników odrzuciłeś światło życia, a zapragnąłeś wiecznych ciemności. Judaszu, dlaczego to uczyniłeś? Biorąc pieniądze zdradziłeś Pana. Judaszu, za trzydzieści srebrników sprzedałeś Stwórcę nieba i ziemi? Co czynisz, Judaszu? W jaki sposób go sprzedajesz? A jeśli go sprzedajesz, to przynajmniej pomyśl, w jaki sposób sprzedajesz! Jeśli byłby sługą jakiegoś rzemiosła, za ile byś go 
sprzedał? - sądzę, że za więcej niż za trzydzieści złotników z racji jego biegłości w rzemiośle; Tego zaś, który w ciagu sześciu dni własną mocą uczynił cały świat, sprzedałeś, nieszczęśniku, za trzydzieści srebrników?” (533 A-B).

Gdy chór umilkł, kaznodzieja przenosi całą scenerię do ogrodu Getsemani, gdzie Jezus się modli i smuci z powodu zdrady Judasza, a następnie podnosi się i mówi do swych uczniów: „Smutna jest moja dusza aż do śmierci” (Mt 26, 38). Słysząc to stojący obok szatan uważał, jak komentuje mówca, iż Jezus smuci się dlatego, że boi się śmierci, stąd też pospieszał, by postawiono krzyż. Chór zaś kończy całą tę scenę piękną, pełną delikatnych uczuć strofą, ocalałą w swym metrycznym wyrazie:

„O serce Pana! Smucił się z powodu zdrajcy, a nie z powodu śmierci; śmierci się nie bał, bo był nieśmiertelny" (536A).

Późniejsi kopiści homilii, ujęci zapewne elegancją tej ostatniej strofy, nie odważyli się popsuć jej wewnętrznej piękności i harmonii wiersza, i dlatego wiernie ją przepisali.

Warto tu jeszcze dodać, że homilia ta według tradycji syryjskiej, poświadczonej w kodeksach arabskich, miała być wykorzystywana (być może w dramatyzowany sposób, z podziałem ról, czytana lub deklamowana) liturgicznie w poniedziałek (Paris arabe 260) lub w nocy we środę Wielkiego Tygodnia, nazywaną, ,środą strachu i terroru" "39.

4. Homilia o Diable i Hadesie [Orkusie] ${ }^{40}$ - poświadczona w 23 greckich kodeksach, przypisywana najczęściej „błogosławionemu Euzebiuszowi”, z czego wydawcy wnioskowali, że należy ona do Euzebiusza z Emezy (np. Augusti, 1820) lub do Euzebiusza Aleksandryjskiego (Thilo, 1832; Mai, 1843; Migne, 1860); sąjednak i tacy, którzy jej autorstwo przypisywali Janowi Chryzostomowi, a nawet Metodemu z Konstantynopola ${ }^{41}$. Mowa ta jest w swej strukturze w całości poszerzonym retorycznie dialogiem władców podziemia - Szatana i Hadesa z Ewangelii Nikodema, przerażonych wiadomością o zbliżającym się zstąpieniu Chrystusa do otchłani i wynikających z tego faktu groźnych dla nich konsekwencji. Trzeba tu jeszcze dodać, że prawie z tego samego

${ }^{39}$ Por. Sauget, La version arabe de l'homélie „Sur la trahison de Judas”, s. 6 i 8.

${ }^{40}$ Ps-Eusebius Alexandrinus, Homilia [XV] in Diabolum et Hadem (= Orcum) [CPG 5524], PG 86, 383-406, tłum. N. Widok (rękopis); por. La Piana, Le rappresentazioni sacre, s. 93-95.

${ }^{41}$ Przypisywana Euzebiuszowi z Emezy por. J.C.G. Augusti, Eusebii Emeseni oratio in sacrum Parasceves diem e duobus codicibus Vindobonensibus nunc in primum in lucem edita, Bonn 1820, 9-17 i 29-35; Euzebiuszowi Aleksandryjskiemu por. T.C. Thilo, Ueber die Schriften des Eusebius von Alexandrien und des Eusebius von Emisa, Halle 1832; J.A. Mai, Spicilegium Romanum, vol. 9 , Roma 1843, 696-703; J. Migne, PG 86, Paris 1860, 383-406; Janowi Chryzostomowi i Metodemu z Konstantynopola por. Lafontaine, La version arménienne du sermon d'Eusebe d'Alexandrie ,, Sur la trahison de Judas", s. 337, n. 16 ; zob. In sancta et magna Parasceve et in sanctam Passionem Domini, PG 62, 721-724, a o innych autorach zob. Lafontaine, La version arménienne du sermon d'Eusebe d'Alexandrie ,, Sur la trahison de Judas”, s. 336-337 i 339. 
czasu (V-VI w., a według niektórych IX w.) pochodzi dokonany przez samego autora lub kogoś innego połączenie tejże Mowy o Diable i Hadesie z kolejną [XVII] O męce Chrystusa (De Christi passione) również Euzebiusza Aleksandryjskiego, przełożone na język łaciński pt. De confusione Diaboli ${ }^{42}$, które według J.G. Thilo już wtedy tworzyły z sobą całość historii, jakby swego rodzaju mały dramat złożony z dwóch rozdziałów - scen o zstapieniu Chrystusa do otchłani, wykorzystywany w Wielki Tydzień: jeden w czasie od Wielkiego Poniedziałku do Wielkiego Czwartku, a drugi w Wielki Piątek ${ }^{43}$. Zaprezentujemy teraz prawie w całości Homilię o Diable i Hadesie, będącą jednym wielkim dialogiem tych dwóch postaci, deklamowanym zapewne w dramatyczny sposób (z podziałem ról) podczas liturgii Wielkiego Piątku. Pierwszy z nich uradowany przebiegającymi po jego myśli wydarzeniami, zachęca drugiego do przygotowania zabezpieczonego miejsca dla mającego wkrótce przybyć do otchłani Jezusa, drugi zaś wzbrania się przed tym, lękając się nowego Gościa. Diabeł usłyszawszy, iż Pan powiedział: «Smutna jest dusza moja aż do śmierci» (Mt 26,38), uwierzył, że boi się On śmierci i krzyża, a podbiegając do Hadesa powiedział:

Diabel: „Bracie Hadesie, bądź gotów do uczynienia kolejnego zła, gdyż ty i ja codziennie nim się zajmujemy. Przygotuj odpowiednie miejsce, gdzie zamkniemy tego, który zwie się Jezusem, a o którym Jan i prorocy przepowiadają że nadejdzie i nas obali. Popatrz, w jaki sposób zaplanowałem śmierć dla niego. Przygotowałem gwoździe, zaostrzyłem włócznię, zmieszałem ocet winny z żółcią, nakłoniłem Żydów, by rzucali w niego, a jego ucznia doprowadziłem do zdrady. Ty bądź jedynie gotów na jego przyjęcie, ponieważ pozostały mu jeszcze tylko dwa dni, a przyprowadzę go do ciebie.

Wiele zła wyrządził mi on na ziemi i przez to mnie rozdrażnił, gdyż zniszczył wiele moich planów. Tych, których ja zbrodniczo zgładziłem, on ich słowem wskrzesił, komu członki ciała poluzowałem, on je słowem złączył i kazał wziąć łoże na ramiona. Innych oślepiłem zabrawszy im światło i cieszyłem się z tego, kiedy burzyli mury, rzucali się do wody i wpadali w błoto, a on przybywszy nie wiadomo skąd i czyniąc mi na przekór, jedynie poprzez swoje słowo obdarował ich szczodrze światłem, i polecił, by ślepy od urodzenia obmył się błotem i wodą z sadzawki Siloe, a ten natychmiast odzyskał wzrok. Potem, gdy nie miałem miejsca, gdzie by się udać, zabrałem z sobą moich pomocników i odszedłem daleko od niego, a znalazłszy pięknego młodzieńca wszedłem w niego i zamieszkałem w nim. Nie wiem, skąd się o tym dowiedział, bo przyszedł tam i rozkazał mi z niego wyjść. Kiedy zaś wyszedłem i znów nie miałem miejsca, gdzie by się udać, poprosiłem go przynaj-

${ }^{42}$ Por. E.K. Rand, Sermo de confusione Diaboli, „Modern Philology” 2 (1904) 261-278; O. Hey, Eine Rede über Christi Höllenfahrt, „Archiv für Lateinische Lexikographie und Grammatik" 14 (1906) 253-268.

${ }^{43}$ Por. Thilo, Ueber die Schriften des Eusebius von Alexandrien und des Eusebius von Emisa, s. 84, n. 1; Rand, Sermo de confusione Diaboli, s. 3. 
mniej o władzę nad świniami, a po wejściu w nie, zadusiłem je. Innego razu, gdy umarła jedyna córka jakiegoś dostojnika i wielki ból ogarnął rodziców z powodu ukochanej dziewczynki, cieszyłem się, kiedy rodzice płakali i byli pogrążeni w żałobie, a reszta tłumu lamentowała aż nastąpił wielki zamęt. Nie wiem, skąd znów on przybył, zbudził ją słowem i oddał matce. Potem zawładnąłem pewną kobietą do tego stopnia, iż przez dwanaście lat wypływały z niej potoki krwi. Gdy go zobaczyła, podeszła do niego, i zaledwie dotknęła brzegu jego szaty, a od razu krew przestała z niej wypływać.

Znajdowałem się daleko od niego i nie odważyłem się wypowiedzieć mu walki, ale zebrałem się i odszedłem z tych stron, w których przebywał. Udałem się na tereny Syrii, a raczej na granice Kananejczyków i znalazłem tam piękną dziewczynę, a wszedłszy w nią, zamieszkałem w niej i czyniłem z nią rzeczy pełne grozy: raz bowiem rzuciłem ją w ogień, innym znów razem pędziłem ją w góry, kiedy indziej wrzuciłem do rzeki. Cieszyłem się z niej, zwłaszcza gdy jej matka cierpiała i była pogrążona w bólu. Gdy on się o tym dowiedział, nie wiem, w jaki sposób przybył na te tereny i pozostał na nich. Matka zaś dziewczyny po usłyszeniu o tym, udała się natychmiast do niego i opowiedziała mu o swojej córce: «Ulituj się nade mną Panie, Synu Dawida! Córka moja jest ciężko opętana przez demona» (Mt 15, 22). On jednak nie odpowiedział jej nawet słowem. Zrozumiałem więc, że nie będzie troszczył się o Kananejczyków i że nadal będę miał ich w swej mocy. Owa kobieta znów podeszła i błagała go mówiąc: «Ulituj się nade mną Panie, Synu Dawida! Moja córka jest ciężko opętana przez demona». On zaś w odpowiedzi rzekł do niej: «Kobieto, wielka jest twoja wiara, niech ci się stanie, jak tego chcesz» (Mt 15, 28). Sam jednak nie podszedł do dziecka, lecz dał tej kobiecie moc wypędzenia mnie i musiałem wyjść z tej dziewczyny, a widząc, że on tam pozostaje, przeniosłem się do Betanii. Tam spotkałem jego przyjaciela Łazarza, a widząc, że droga jego życia jest długa, postanowiłem go zmęczyć, porwałem go i przyprowadziłem do ciebie, mój bracie Hadesie. Byłem spokojny, uważając, że nikt go już od ciebie porwać nie może. Tymczasem po czterech dniach on tam przybył, i nie wiem jak to się stało, czy byłeś zmorzony snem, czy też odwiedzałeś inne miejsca, on ci go wyrwał”.

Hades: „Czy on jest tym, który wówczas porwał mi Łazarza? Jeżeli to on, to zlituj się nade mną i nie przyprowadzaj go tutaj. On jest potężny, jego głos mnie wówczas przeraził i odebrał wszelką siłę. Nie mogłem znieść jego głosu,czy ty natomiast zamierzasz go zamknąć tutaj? Oby tak się nie stało! Zlituj się nade mną, ale ja nie mogę go przyjąć tutaj. Jeżeli on tu przyjdzie, to wyzwoli tych, których tu mam. Bracie, ja wówczas pozwoliłem, by zgniło ciało Łazarza, mając go przez cztery dni pod swą opieką. Już zaczął cuchnąć, już zaczęły się rozluźniać wiązadła członków jego ciała i w ogóle zapanowałem nad nim. Kiedy jednak on przybył pod moje drzwi i zawołał do niego: «Wyjdź tutaj», ów cuchnący Łazarz wyrwał się z moich rąk, jak lew wychodzący z jaskini na żer, uniósł się jak orzeł tracąc w mgnieniu oka całą swą słabość". 
Diabel: „Ty tchórzu, niegodny męża, to mnie wyrządzono tak wiele zła, a nie zszedłem ze świata, ani też nie zaprzestałem walki z ludźmi, natomiast ty po doznaniu jednej tylko porażki już tchórzysz? Mimo, iż doznałem z jego strony tak wiele zła, nie zaprzestałem nienawidzić ludzi. Kiedy zaś zobaczyłem, że on leczy niemoc ciała bez dotykania go, zająłem się niszczeniem dusz ludzkich poprzez swoje działania. Spotkawszy pewnego młodzieńca imieniem Mateusz i napełniwszy jego serce żądzą bogacenia się, zapanowałem nad nim i zrobiłem go poborcą regionalnych podatków. Ten zaś młodzieniec do tego stopnia mnie słuchał, że łupił i rabował wszystkich, odbierając im nadzieję, bijąc i policzkując, pożerając i pijąc cudzy majątek. Stał się on moim poddanym i cieszyłem się z tego powodu, że tak wspaniale wypełnia moje plany, a i dla siebie zebrał on wiele bogactw. Gdy umieściłem go jako niezawodnego wykonawcę mojej woli w miejscu, gdzie pobiera się podatki, on znów nie wiem skąd przybył, i podchodząc do młodzieńca rzekł do niego: «Pójdź za mną» (Mt 9, 9). Mateusz zaś wezwany jego słowem natychmiast podniósł się oraz opuścił dom i majątek, który pozwoliłem mu z tak wielkim trudem zgromadzić. Nie dał się przekonać nawet rodzicom, lecz słyszał jedynie jego głos, natychmiast poszedł za nim i stał się jego uczniem. Kiedy to zobaczyłem, strasznie się zasmuciłem, że tak dobry sługa oderwał się ode mnie. Lecz mimo to nie zaprzestałem go nienawidzić, przypuszczając, że porwał mi go z miłości do młodego wieku.

I znów powstawszy udałem się w drogę do krainy Jerycha. A gdy tam znalazłem niskiego i prostego człowieka imieniem Zacheusz, wszedłem w niego i postawiłem na czele domu podatkowego. On nieco złagodził mój smutek z powodu straty Mateusza. Uspokoiłem się uważając, że teraz już nikt mi go nie zabierze, ponieważ był on wyjątkowo brzydki i mały. I znów nie wiem, skąd przybył on tam wraz z tłumem. Zacheusz, ponieważ był niski i nie mógł zobaczyć, kto nadchodzi, wszedł na sykomorę, tamten zaś spojrzał w górę, zauważył go i rzekł: «Zacheuszu, zejdź szybko!» (Łk 19, 5). Zacheusz przyjął to z radością, a po zejściu dał natychmiast poczwórną zapłatę każdemu z tych, których wcześniej łupił, połowę zaś swego majątku rozdał biednym, stając się jego przyjacielem, a moim wrogiem. Nie znajdując już miejsca, gdzie mógłbym się udać (wszyscy bowiem moi przyłączyli się do niego), dalej kusiłem grzeszników zachęcając ich: Grzeszcie dalej, nie odstępujcie od swych przyjemności, dopóki nie nadejdzie koniec, a i wówczas niech wam nie zabraknie na to środków. Mówiąc tak i temu podobnie, nakłaniałem ich, by nie zważali na własne dusze i pogrążali się w rozkoszach zła. Ale przyszedł on i zaczął mówić przeciwnie: usprawiedliwiał grzeszników, tym którzy się nawrócą - obiecywał królestwo niebieskie, a tym którzy poczują skruchę - odpuszczenie grzechów i spłacenie długów; do wszystkich zaś wołał: «Pójdźcie wszyscy, którzy pracujecie i obciążeni jesteście, a ja was ochłodzę» (Mt 11, 28). W ten sposób przyciagnął do siebie wszystkich i wszyscy przyłączyli się do niego. Kiedy już nie znajdywałem miejsca, gdzie bym mógł odejść, 
przypomniałem sobie dawną przyjaźń i udałem się do moich starych przyjaciół - Żydów, których kiedyś uczyłem czcić cielca. Przypomniałem sobie ich dawne uczucia do mnie i przybywszy do nich podburzyłem ich, wraz z kapłanami przeciwko Niemu. Ty się go więc nie bój, ale przygotuj odpowiednie miejsce, gdzie go zamkniemy".

Hades: „Nie pojąłem chyba dobrze twoich złych słów, które skierowałeś do mnie przeciw niemu. Ale trzymaj się z dala od niego, i nie próbuj go sprowadzać tutaj, bo ja nie mogę go tu przyjąć. Cóż ty masz z nim wspólnego? Co łączy garnek gliniany z saganem? Tak samo cię uderzy i rozbije na kawałki. On wyrządził ci tak wiele zła, zabrał ci tak wielkich pomocników, jak mówisz, celników, zuchwalców, rozpustników, tak iż nie odważyłeś się stanąć przed jego obliczem, ani odezwać się do niego, a teraz chcesz przyprowadzać go tutaj, aby odebrać moją nadzieję i uczynić mnie podobnym do ciebie pozbawionym nadziei? Jeśliby on nie był Synem Bożym, nie czyniłby takich cudów. Jeśliby był tylko człowiekiem, nie mógłby leczyć cielesnych niemocy, ani nakłaniać serca celników i grzeszników do zmiany życia i nawrócenia. Powiedziałeś też, że jednym słowem nakłonił celnika, by opuścił dom podatkowy i poszedł za nim, ty zaś nie odważyłeś się nawet stanąć przed nim, a mnie zachęcasz, bym go zamknął? Dobrze wiem, co o nim mówią prorocy, których mam zamkniętych u siebie, z jaką radością czekają na niego. Wiem też, co po swym przyjściu tutaj obwieścił o nim sam Jan, i dlatego boję się go tu przyjąć".

Diabel: „Oni wszyscy kłamią, by cię przestraszyć”.

Hades: „Lecz nie skłamali w tym, co wcześniej powiedzieli o tobie, co ci uczynił ten, który nazywa się Jezus. Ty sam przyznałeś mi się do tego, pod ręką są zresztą ich słowa, teraz zaś nazywasz ich kłamcami?’”.

Diabel: „Masz przecież potężne siły i wygłodniałe wnętrze, którego nikt nie może zaspokoić, a nie możesz przyjąć jeszcze jednego człowieka?”.

Hades: „Nie pleć już dłużej głupstw. Wszyscy bowiem, którzy cię opuścili, przyłączyli się do niego. Jasne jest więc, że i ty zamierzasz mnie opuścić i stać się Jego przyjacielem".

Diabel: „Cały świat przyjąłeś i nie powiedziałeś - dość! Przyjąłeś Abrahama, Izaaka, Jakuba, wszystkich proroków i nie stchórzyłeś, a teraz z powodu jednego człowieka mojego wroga, popadłeś w tak wielkie tchórzostwo i nie chcesz go przyjąć? To ja sprawiłem, że ten człowiek boi się Śmierci. Teraz bowiem, kiedy zrozumiał, że nadchodzi pora jego śmierci, bojąc się mówi ze smutkiem: «Smutna jest dusza moja aż do śmierci?» (Mt 26, 38)».

Hades: „Nie widziałem go, ani też nie pragnę go widzieć. Posłuchaj mnie, a mówię ci prawdę, przestrzegaj moich słów, on tak zmyślnie mówi, abyś upadł przed jego obliczem i aby ci się stało jeszcze coś gorszego. Biada ci 
nieszczęsny! Z chęci wyśmiania cię powiedział te słowa. Odejdź od niego i nie walcz z nim".

Diabel: „Mam potężnych pomocników i nie boję się z nim walczyć. Podobnie usposobieni są Annasz, Kajfasz i Judasz. Oni są moimi wspólnikami. Mamy też przy sobie pozostały tłum Żydów i możemy zrobić z nim, co tylko zechcemy. Ty go jedynie przyjmij!"

Hades: „Idź i czyń co chcesz, wypowiedz wojnę! Jeżeli go zwyciężysz, to przyjmiemy go tutaj, a ty będziesz panował razem z Żydami. Jeżeli zaś zostaniesz pokonany, on przyjdzie tu i wyzwoli tych, których mam w zamknięciu, oraz zwiąże cię razem z Żydami, odda mi was, i razem staniemy się nieszczęśliwi” (385-401).

Mówca objaśnia dalej, że Diabeł udał się do Żydów, by ich podburzać przeciwko Chrystusowi, ci zaś zebrawszy się postanowili go zabić.

\section{Męka i śmierć Chrystusa}

oraz Jego zstąpienie do otchłani

5. Homilia o męce Chrystusa ${ }^{44}$ - kolejna mowa z euzebiańskiego cyklu o zstapieniu Jezusa do otchłani, poświadczona w 47 greckich kodeksach, przez długie lata przypisywana (28 kodeksów) Janowi Chryzostomowi (Saville, 1612; Montfaucon, 1734; Migne, 1860), potem po raz pierwszy Euzebiuszowi z Aleksandrii (= 15 kod.; Thilo, 1832), a nawet Atanazemu Aleksandryjskiemu (= 1 kod.) i biskupowi Ewagriuszowi (1 kod.), by ostatecznie jej autorstwo przyznać tajemniczemu Biskupowi Aleksandrii ${ }^{45}$. Wnet po jej napisaniu dołączono ją, jak zaznaczaliśmy wyżej, do również euzebiańskiej Mowy o Diable i Hadesie, przełożono na język łaciński i rozpowszechniono jako całość pt. De confusione Diaboli. W swej strukturze homilia ta opisuje krótko najpierw pojmanie Jezusa (ułatwione zdradzieckim pocałunkiem Judasza, Jego osądzenie, biczowanie, cierniem ukoronowanie, skazanie i śmierć na krzyżu, wywołujące dziwne zjawiska na niebie i na ziemi - o czym opowiada chór, a następnie jedyny w tej z euzebiańskich homilii ukazany przebieg zstąpienia Chrystusa do otchłani, wywołujący tam popłoch Szatana i Hadesa oraz

${ }^{44}$ Ps-Eusebius Alexandrinus, Homilia [XVII] de Christi Passione [CPG 5526], PG 62, 721-724; por. La Piana, Le rappresentazioni sacre, s. 95; M. Gronewald, Kein durchtriebener Räuber (P. Lit. Lond. 245 = Ps-Eusebius, Sermo 17), „Zeitschrift für Papyrologie und Epigraphik” 34 (1979) 2225; G. Lafontaine, La version arménienne du sermon d'Eusebe d'Alexandrie „, Sur la Passion du Seigneur”, „Le Muséon” 95 (1982) 99-113; Skrzyniarz, Hades. Recepcja, s. 62.

${ }^{45}$ Janowi Chryzostomowi por. H. Savilius, S. Joannis Chrysostomici opera graece, vol. 7, Paris 1612, 459-462; B. de Montfaucon, Sancti Patris nostri Johannis Chrysostomici... opera omnia quae exstant, vol. 11, Paris 1734, 793-796; J. Migne, PG 62, Paris 1860, 721-724; Euzebiuszowi Aleksandryjskiemu por. Thilo, Ueber die Schriften des Eusebius von Alexandrien und des Eusebius von Emisa, s. 81-91; które kodeksy im ją przypisują zob. Lafontaine, La version arménienne du sermon d'Eusebe d'Alexandrie „, Sur la Passion du Seigneur”, s. 99-101. 
ich dramatyczny dialog, do którego dołączają się także Jan Chrzciciel, król Dawid, prorocy, a nawet nawrócony łotr. Na jej wstępie kaznodzieja opisuje również krótko zorganizowane wystąpienie Żydów przeciw Jezusowi oraz Jego pojmanie w Ogrojcu, ułatwione przez zdradziecki pocałunek Judasza. Gest ten z oburzeniem zdaje się przyjmować śledzący nadal akcję zdrajcy chór, który porównuje serią antytez pocałunek Judasza do pocałunku pokutującej Marii Magdaleny:

„O podstępny, pełen niegodziwości i zguby pocałunku! O gorzki, ściagający na duszę zgubę i piekło pocałunku! Nierządnica całowaniem stóp Pana wyrwała swą duszę z błota, a ten pocałunkiem wymazał się z księgi życia. O filozofio kobiety! O głupoto ucznia! Z całowania stóp Pana cieszą się aniołowie i przygotowują jej koronę, z tego zaś pocałunku radują się szatani, którzy zadzierzgnęli pętlę zguby. «Witaj, Rabbi», szatan się cieszy, ty zaś, Judaszu, smucisz, że zostałeś pozbawiony radości” (721B).

Kaznodzieja opisuje dalej zwięźle oskarżenie Jezusa przez najwyższych kapłanów żydowskich, Jego ubiczowanie, cierniem koronowanie i skazanie na śmierć przez Piłata oraz ukrzyżowanie. W odpowiedzi na to ostatnie znów zdaje się wkraczać chór i porównywać w formie antytez drzewo krzyża z drzewem rajskim:

„Nosi na głowie koronę cierniową, aby nas uwolnić od rzuconego na nas przekleństwa; na drzewie został ukrzyżowany, aby zniweczył grzech popełniony przez drzewo. Przez drzewo szatan wypędził z raju Adama i przez drzewo Pan uczynił obywatelem raju łotra" (721D).

Myśl chóru uzupełnia kaznodzieja uwagą, że jak Bóg w szóstym dniu uformował ciało Adama i w szóstym dniu wypędził go z raju, tak też Pan w szóstym dniu otworzył raj i wprowadził do niego łotra. Tymczasem szatan widząc co się wokół dzieje w związku ze śmiercią Chrystusa: zaćmienie słońca, drżenie ziemi, pęknięcie zasłony świątyni, pękanie skał, otwieranie się grobów i powstanie umarłych (Mt 27, 51-52) przerażony biegnie do Hadesa:

Szatan: „Biada mi nędznemu! Zostałem ośmieszony! Pomóż mi w biedzie! Zamknijmy wejścia, aby tu nie wszedł! Wzmocnij zasuwy i wszelkimi siłami przeciwdziałajmy, aby go tu nie wpuścić!" (722C).

W odpowiedzi na to wołanie „Hades pobiegł, zamknął drzwi i wzmocnił, jak objaśnia kaznodzieja, żelazne zapory”. Tymczasem w otchłani zjawia się poszukujący szatana Chrystus, poprzedzany przez niebieskie Moce, które wołają:

Moce: „Bramy, podnieście swe szczyty i unieście się prastare podwoje, aby mógł wkroczyć Król chwały (Ps 24, 9)”.

Hades [z wewnątrz]: „Któż jest tym Królem chwały?” (Ps 24, 10).

Moce: „To Pan zastępów, On sam jest Królem chwały”. 
Hades: „Kim jest ten, o którym mówicie? Jeśli jest takim, to czego tutaj szuka? Dlaczego zostawił niebo i zszedł tutaj?"

Moce: „Jest Królem chwały i przychodzi, aby tego, który z powodu buntu został potępiony, związać i przekazać ci oraz wywołać i wyprowadzić od ciebie swoje wojska".

Hades [do szatana]: „Trójgłowy Belzebubie, wyrzutku aniołów, pośmiewisko świętych, chuderlaku, ślepcu, czy ci nie mówiłem, abyś z nim nie walczył? Oto masz teraz to, co ci przepowiedziałem. Co czynisz, nędzniku? On przychodzi, aby cię schwytać i związać, a przez ciebie i ja zostanę jeńcem. Wyjdź, jeśli możesz, stań naprzeciw i walcz z nim. Ja bowiem nie jestem w stanie ci pomóc".

Szatan: „Zlituj się nade mną przynajmniej teraz i nie otwieraj. Broń mnie choć teraz, gdy zostałem ośmieszony. Któż bowiem nie dałby się oszukać tego rodzaju jego słowami, kiedy bojąc się śmierci mówił: «smutna jest dusza moja aż do śmierci» lub kiedy kierował do Ojca błaganie: «Ojcze, jeżeli to możliwe, niech odejdzie ode mnie ten kielich» (Mt 26, 38-39) - te słowa mnie zdradziecko zwiodły".

Hades: „Również ja biedny na ich podstawie podejrzewałem, że on cierpi bojąc się śmierci" (722D - 723A).

Podczas tego rodzaju rozmów Moce niebieskie powtarzały z uporem: „Bramy podnieście swe szczyty i unieście swe prastare podwoje, by mógł wkroczyć Król chwały”, ,a prorocy słysząc głos Króla chwały cieszyli się i wychwalali Boga”. Do akcji włącza się tymczasem przebywający tam Jan Chrzciciel i król Dawid.

Jan: „Czy nie mówiłem wam, że przyjdzie, aby nas wyprowadzić?”

Dawid: „Pozwólcie, aby się wypełniło moje proroctwo. Gdy bowiem byłem jeszcze na ziemi, przewidywałem, że te bramy nie otworzą się łatwo i dobrowolnie, dlatego też mówiłem: «Pan tocząc walkę, bramy spiżowe wyłamał i skruszył żelazne wrzeciądze» (Ps 106, 16)" (723B-C).

Tymczasem w otchłani zjawił się Chrystus, który, jak opowiada dalej kaznodzieja, obalił wszelkie bramy, złamał zasuwy, podeptał piekielne moce, zniweczył bóle śmierci i zmniejszył udręki otchłani. Wówczas to wypełniły się słowa: „Gdzie jest, piekło, twoje zwycięstwo? Gdzież jest, o śmierci, twój oścień?" (1Kor 15, 55). Zbiegający się zaś prorocy uradowani śpiewali Mu hymny. Pan natomiast schwytawszy szatana związał go nierozerwalnymi pętami i poprowadził go do najniższych czeluści piekła oraz umieścił go w niegasnącym ogniu, gdzie w zamknięciu jęczał i płakał. Do wyprowadzonych zaś z otchłani proroków powiedział: „Chodźcie do raju”. Ci zaś uradowani wyszli z otchłani i dziękując Panu za wyzwolenie przybyli do raju, gdzie ze zdziwieniem spotkali łotra: 
Prorocy: „Kto cię tu przyprowadził? Kto ci otworzył bramy? Kto to sprawił, że przed nami tu wszedłeś? A może przyszedłeś, by to, co tu jest, zrabować i splądrować? Nie dość ci było rabowania rzeczy ziemskich, czy także niebieskie chcesz rabować? Powiedz nam, kto cię tu wprowadził? Nie zazdrościmy ci, że tu wszedłeś, ale podaj nam powód swego tu przybycia”.

Łotr: „Nie z powodu moich czynów tu wszedłem, ale łaskawy i miłosierny Pan mnie tu wprowadził. Nie było we mnie nic dobrego i dlatego Żydzi skazali mnie na śmierć razem z nieśmiertelnym Królem: chcąc mnie zabić, raczej mnie ożywili krzyżując z Chrystusem. Widziałem cuda zdziałane na krzyżu i przypuszczając, że on jest Synem Bożym, zawołałem wielkim głosem: «Panie, wspomnij na mnie, gdy przyjdziesz do swego królestwa» (Łk 23, 4243). On zaś spełnił zaraz moją prośbę odpowiadając: «Zaprawdę powiadam ci, dziś ze mnę będziesz w raju» oraz dał mi znak krzyża mówiąc: «Weź go i idź do raju, jeśliby ci wejście zagrodził ognisty miecz, pokaż mu ten znak królewski, a otworzy ci bramy». I przyszedłem, ale zaraz mnie spostrzegł miecz ognisty, który strzeże raju i zamknął przede mną bramy. Wówczas powiedziałem: «Przysyła mnie tu Król, który teraz jest ukrzyżowany» i pokazałem mu znak krzyża, a on zaraz mi otworzył. Wszedłem do środka, ale nikogo tam nie znalazłem, a dziwiąc się temu rozważałem: Gdzie jest Abraham, Izaak i pozostały tłum proroków? Gdy tak się zastanawiałem, od strony wschodu zjawiło się dwóch mężów z dawnych dni o przedziwnej postaci i pięknym obliczu, którzy mnie zapytali: «Kim jesteś? Nie jesteś Abrahamem, bo nie nosisz jego kapłańskiego stroju. Nie jesteś też Mojżeszem, bo masz inny głos i język. Kim więc jesteś? Wydajesz się być łotrem, bo twój strój zdradza łotra». Przyznałem się wiec, że jestem łotrem, że Pan raju mnie tu wprowadził, ponieważ byłem towarzyszem jego śmierci, którą za nas poniósł. Ja natomiast zapytałem: «Wy zaś kim jesteście»? Wówczas jeden z nich mi odpowiedział: «Jestem Eliaszem Tesbitą, nie doznałem śmierci, bo zostałem tu przywieziony na wozie ognistym, ten zaś jest Henochem, który słowem Bożym został tu przyniesiony" (724A-C).

Cała homilia kończy się wezwaniem do dziękowania Bogu za łaski odkupienia oraz tradycyjną doksologią.

\section{Homilia o pogrzebaniu Bożego Ciała i zstąpieniu Chrystusa do ot- chłani $^{46}$ - długo przypisywana Epifaniuszowi z Salaminy ( $\left.\uparrow 403\right)$, a potem}

${ }^{46}$ Homilia in divini Corporis sepulturam et de Christi adventu in infernum [CPG 3768], PG 43, 439-463, tłum. R. Sawa (maszynopis); por. La Piana, Le rappresentazioni sacre, s. 95-97; H. De Vis, Homélie cathédrale de Marc patriarche d'Alexandrie, „Le Muséon” 34 (1921) 179-216 i 35 (1922) 17-48; A. Vaillant, L'homélie d'Epiphane sur l'ensevelissement du Christ. Texte vieux-slave, texte grec et traduction francaise, Zagreb 1958; M. Van Esbroeck, Les plus anciens homéliaires géorgiens, Louvain 1980; G. Peradze, Die altchristliche Literatur in der georgischen Überlieferung, III, OC 5 (1930) 86, n. 5 (przypisana Epifaniuszowi, czytana w Wielką Sobotę); G. Graf, Geschichte der christlichen arabischen Literatur, Bd. I (ST 118) Übersetzungen, Città del Vatica- 
Anastazemu Synaicie lub Markowi - patriarsze aleksandryjskiemu, by ostatecznie zostać bez ustalonego autora, bardzo popularna, oraz już w starożytności często liturgicznie wykorzystywana i wielokrotnie thumaczona na języki wschodnie (na syryjski, armeński, gruziński, arabski, a nawet starosłowiański), której fragment cytowany jest także w Liturgii Godzin ${ }^{47}$. Na jej wstępie kaznodzieja posługując się niejako chórem, stara się wprowadzić atmosferę wielkiej ciszy, milczenia i pustki, powstałej po śmierci Chrystusa, oraz zapowiada Jego zejście do otchłani, by uwolnić z niej przebywających tam sprawiedliwych:

„Co się stało? Wielka cisza spowiła dziś ziemię. Wielkie milczenie i pustka, ponieważ Król śpi: ziemia przeraziła się i uciszyła, bo Bóg zasnął w ciele, a tych, którzy spali na wieki - obudził. Bóg w ciele umarł i zatrzą̧ł się Hades. Bóg zasnął na krótko i wskrzesił tych, którzy byli w otchłani. Gdzież są teraz zamieszki sprzed niedawnego czasu i krzyki, i wrzaski przeciw Jezusowi, o bezbożni? Gdzież ciżby ludu, gdzież wrogie wystąpienia i szyki, broń i włócznie? Gdzież królowie i kapłani, sędziowie i skazani? Gdzież pochodnie, miecze i bezładne wrzaski? Gdzież ludy, butność i niegodziwa straż? Sprzeciwili się kamieniowi węgielnemu - Chrystusowi, lecz sami zostali starci; uderzyli w mocną skałę, lecz sami zostali rozbici i w pianę rozproszyły się ich zamysły [...]. Dzisiaj zbawienie dla tych, którzy są na ziemi i tych, którzy od wieków pod ziemią. Dzisiaj zbawienie i dla świata, który jest widzialny, i dla tego, który niewidzialny. Podwójne dziś przyjście Pana, podwójny zarząd, podwójna miłość do ludzi, podwójne zarazem zejście i zniżenie, podwójne nawiedzenie ludzi: z nieba na ziemię, z ziemi zaś pod ziemię schodzi Bóg: otwierają się bramy otchłani. Wy, którzy śpicie od wieków, cieszcie się! Wy, którzy spoczywacie w ciemności i cieniu śmierci, przyjmijcie światłość wielką! Wraz ze sługami Pan; ze zmarłymi Bóg; z umarłymi Życie; z winnymi Niewinny; z tymi, którzy w ciemności - Niezmierzone Światło" (440A-C).

Z kolei mamy opisaną scenę pogrzebania ciała Chrystusa. Kaznodzieja poprzedza ją skierowaną do Piłata prośbą o ciało zmarłego Jezusa: „Pod wieczór przyszedł zamożny człowiek z Arymatei imieniem Józef, udał się do Piłata i poprosił o ciało Jezusa" (Mt 27, 57; Mk 15, 43). W długim przemówieniu zdaje się prosić o rzecz mała, o zwłoki nieznanego człowieka, na co Piłat odpowiada pozytywnie.

Józef z Arymatei: „Sędzio, przybyłem do ciebie, zwracając się z bardzo małą prośbą: Daj mi pogrzebać ciało tego osądzonego przez ciebie Jezusa Nazareńskiego, Jezusa ubogiego, Jezusa bezdomnego, Jezusa powieszonego,

no 1944, 357 (przypisana Epifaniuszowi, czytana w Wielką Sobotę); J.M. Sauget, L’Homéliaire arabe de la Bibliothèque Ambrosienne (X. 198 Sup.) et ses membra disiecta, AnBol 88 (1970) 459460, n. 62 (przypisana Anastazemu Synajskiemu); J.M. Sauget, Deux Homéliaires Syriaques de la Bibliothèque Vaticane. Syriaque 569 n. 37, OCP 27 (1961) 420-421 (przypisana Anastazemu Synajskiemu).

${ }^{47}$ Por. LG II 386-388 (Starożytna homilia na Święta i Wielką Sobotę). 
nagiego, skromnego, Jezusa, syna cieśli, Jezusa związanego, [żyjącego] pod gołym niebem, obcego, nie znającego gościny, lekceważonego i powieszonego za wszystkich. Daj mi tego obcego, bo cóż ci przyjdzie z jego ciała? [...]. Proszę o zmarłego, znieważonego przez wszystkich, sprzedanego przez przyjaciela, zdradzonego przez ucznia, ściganego przez braci i spoliczkowanego przez sługę. Przybywam z poselstwem po zmarłego, oskarżonego przez tych, którzy zostali przez niego uwolnieni, który napojony został octem, który został zraniony przez tych, których wyleczył, pozostawiony przez uczniów, a nawet opuszczony przez matkę. Proszę, panie, o bezdomnego zmarłego, powieszonego na krzyżu. Nie ma on bowiem na ziemi ani ojca, ani przyjaciela, ani ucznia, ani krewnego, ani grabarza, lecz on jeden jest jednorodzonym [Synem] Jedynego Boga" (445C - 448B).

Chór zaś pełnym powagi głosem opisuje zdjęte z krzyża i leżące na ziemi ciało Chrystusa oraz pyta Józefa, jak urządzi mu pogrzeb, jak namaści i przygotuje Jego ciało do pogrzebania, a także dziękuje i błogosławi go za to:

Chór: „Czy uświadamiasz sobie, Józefie, o co prosiłeś i kogo zabrałeś? Czy poszedłszy pod krzyż, zdjąwszy Jezusa, wiesz, kogo zabrałeś? Czy rzeczywiście wiesz, kogo trzymasz, stawszy się teraz zamożnym? Jakże dokonasz tego najstraszniejszego pogrzebania Boskiego ciała Jezusa? Godne pochwały jest twoje pragnienie, ale jeszcze bardziej godny pochwały jest charakter twojej duszy. Czyż bowiem nie lękasz się niosąc na rękach i Tego, którego lękają się cherubinowie? Albo z jakim lękiem odsłonisz całkowicie płótno z owego Boskiego Ciała! Jakże pobożnie spuszczasz oczy! Czyż nie boisz się, patrząc i odsłaniając naturę ciała Boga, Tego który jest ponad naturą? Powiedz mi Józefie, czy pochowasz, zwracając ciało na wschód, zmarłego - Wschód Wschodów? Czyż także zamkniesz swoimi palcami i w sposób godny oczy Tego, który otworzył nieskalanym palcem oko ślepca? Czyż zamkniesz także usta Tego, który otworzył usta niemowy? Czyż owiniesz także całunem ręce Tego, który sprawił, że wyciagnęły się uschnięte ręce? Czyż również owiniesz w sposób godny zmarłego nogi Tego, który pozwolił poruszać się nieruchomym nogom? Czyż także podniesiesz na mary Tego, który zawołał do paralityka: «Weźmij swoje nosze i chodź». Czyż wylejesz także mirrę na Tego, który rozlał Niebiańską Mirrę na siebie i uświęcił świat; czyż odważysz się także otrzeć ów krwawiący aż dotąd Boski bok Jezusa, Boga, który uzdrowił krwawiącą? Czyż również obmyjesz wodą ciało Boga, który obmył wszystkich i dał oczyszczenie? Jakie zapalisz lampy Prawdziwemu Światłu, które oświeciło każdego człowieka? Jakie zaśpiewasz pieśni pogrzebowe Temu, którego bezustannie opiewa całe Wojsko Niebieskie? Czyż także będziesz ronił łzy nad zmarłym, który je uronił wskrzeszając martwego od czterech dni Łazarza? Czyż użalisz się nad Tym, który wszystkim dał radość i rozproszył smutek Ewy? [...].

Błogosławię, Józefie, twoje ręce, którymi oddałeś posługę i dotykałeś jeszcze krwawiących Boskich rąk i nóg Jezusa; błogosławię twoje ręce, 
którymi dotykałeś krwawiącego boku Boga przed niewiernym i godnym pochwały za swoją ciekawość Tomaszem; błogosławię twoje usta, które zostały napełnione w nienasyceniu i zjednoczone z ustami Jezusa, napełnione stamtąd Duchem Świętym; błogosławię twoje oczy utkwione w oczach Jezusa i czerpiące stamtąd światło prawdy; błogosławię twoją twarz, która zbliżyła się do twarzy Boga; błogosławię twoje ramiona, które niosły Tego, który unosi wszystkich; błogosławię twoją głowę, do której przybliżył się Jezus - Głowa wszystkich; błogosławię twoje ręce, którymi podniosłeś Tego, który unosi wszystko" (448C - 449C).

W pogrzebie Jezusa obok Józefa biorą również udział Nikodem, aniołowie i różne Moce niebieskie, które zbiegają się i ze zdumieniem pytają:

Moce: „Cóż to za straszliwe słowo, strach i lęk, i zachowanie? Cóż to za wielkie, niepojęte i niezrozumiałe widowisko? Ten, który w górze dla nas bezcielesnych jest niewidoczny, na dole dla śmiertelnych stał się widoczny. Tego, przed którym z lękiem stoją cherubinowie, Józef i Nikodem grzebią bez lęku. Kiedyż tu zszedł Ten, który Wysokości nie opuszczał? Jakże wyszedł Ten, który pozostaje wewnątrz? Jakże przyszedł na ziemię Ten, który wszystko wypełnia? [...]. Jakże Ten, którego nic nie ogranicza, będzie ograniczony grobem? Jakże zamieszka $\mathrm{w}$ grobie Ten, który nie opuścił ojcowskiego łona? Jakże wchodzi w bramy lochu Ten, który otworzył bramy raju?” (449D - 452A).

Scena jednak się zmienia i przenosi do otchłani, do której zstępuje Chrystus wraz ze swymi niebieskimi Mocami i aniołami, aby uwolnić uwięzionych tam sprawiedliwych. Zaczyna się jakby zdobywanie otchłani: najpierw prośba o jej otwarcie, a później walka i pokonanie jej władców.

Archaniol Gabriel: „Podnieście, władcy, bramy wasze” (Ps 24, 7).

Michal: „Unieście się prastare podwoje” (Ps 24, 7).

Moce: „Odstąpcie, niegodziwi odźwierni!”

Potęgi: „Bądźcie zniszczone, nierozerwalne łańcuchy!”

Moce: „Wstydźcie się, wrodzy nieprzyjaciele! Lękajcie się, niegodziwi tyrani!"

Zastępy nieba: „Podnieście, władcy, bramy wasze! Nie otwierajcie, lecz ruszcie je z ich posad, zniszczcie, przenieście, aby się już nie zamknęły; Podnieście, władcy, bramy wasze! Potężny jest bowiem obecny tu Pan i jeżeli chce, może wejść mimo zamkniętych bram, lecz jak zbiegłym niewolnikom nakazuje wam uchylenie odwiecznych bram, ich przeniesienie i rozbicie. Tym którzy u was uchodzą za władców, rozkazuje: Podnieście, władcy, bramy wasze! [...]. Jeżeli bowiem aż dotąd źle rządziliście tymi, którzy spoczywają od wieków, już nie ich, ani żadnych innych, lecz tylko was, a nawet was samych nie jesteście władcami. Pojawia się bowiem Chrystus - Brama Niebieska: «Czyńcie drogę 
Temu, który wstępuje na zachód, którego imię jest Pan i u Pana są wyjścia przez bramy śmierci» (Ps 66, 5). Wy uczyniliście wejścia; aby uczynić wyjścia On sam się pojawił. Dlatego nie wahajcie się: Podnieście bramy i pospieszcie się: unieście i nie wstrzymujcie się. Jeżeli zaś uważacie, że powinniście zwlekać, zwrócimy się do tych bram sami i z własnej woli” (457A-C).

Komentator w dramatyczny sposób odmalowuje popłoch i przerażenie, jakie wywołały w otchłani pojawienie się Chrystusa i powyższe wołania:

„Usunęły się bramy, rozluźniły się łańcuchy, rozpadły się rygle, opadły zamki, poruszyły się fundamenty więzienia, a wrogie podziemne moce rzuciły się do ucieczki, jedna drugą popychając i wpadając na siebie, wzywając jedna drugą do ucieczki. Przeraziły się, były wstrząśnięte, zatrwożyły się, wpadły w popłoch, zmieniły się, zmąciły się, powstały i osłupiały, stały się bezradne i zadrżały $\mathrm{z}$ trwogi. Jeden z władców podziemi stanął z rozdziawionymi ustami, drugi ukrył twarz w kolanach, inny leżał rozciagnięty na ziemi z rozkrzyżowanymi rękami, kolejny znieruchomiał jak martwy, jeszcze inny przerażony był tym cudem, a inny leżał zmieniony, inny wreszcie uciekł do wewnątrz" (457D).

Przerażeni władcy otchłani: „«Któż jest tym Królem chwały» (Ps 24, 8). Kimże jest ten tak wielki, który dokonuje tutaj takich cudów? Któż jest tym Królem chwały, który w otchłani czyni teraz te rzeczy, jakie nigdy się w otchłani nie zdarzyły? Kimże jest ów, który wyprowadza stąd tych, którzy spoczywają tu od wieków? Kimże jest ten, który uwalnia nas, niszczy zuchwałość i siłę nas niezwyciężonych, i wyprowadza z więzienia otchłani tych, którzy byli związani od wieków?"

Moce Pana: „Chcecie się dowiedzieć, niegodziwi tyrani, któż jest tym Królem chwały? «Pan mocny i potężny, Pan potężny, silny i niezwyciężony w bitwach» (Ps 24, 8). On jest tym, który wygnał was i zrzucił ze sklepienia niebieskiego, tchórzliwi i niegodziwi tyrani! On jest tym, który starł w wodach Jordanu głowy wężów waszych. On jest tym, który was przez Krzyż skazał, zatriumfował nad wami i zniweczył. On jest tym, który was związał, przyćmił i strącił do otchłani. On jest tym, który was wrzucił w ogień wieczny, do piekła i zniszczył. Nie wahajcie się więc i nie zwlekajcie, lecz pospieszcie się i wyprowadźcie więźniów, których aż dotąd niegodziwie dręczycie; wasza władza została zniszczona; kończy się wasza tyrania; wasza pycha została ograniczona; wasza chełpliwość została wykończona, wasza siła została zdeptana i zniesiona" (460A-C).

W odpowiedzi na to, jak objaśnia komentator, nastąpiło zwycięskie zdobycie i niszczenie otchłani, jej przeszukiwanie i zwalnianie tam uwięzionych:

„Jedni niszczyli więzienie doszczętnie, do fundamentów, inni zaś ścigali wrogie potęgi uciekające z zewnętrznych zakamarków do wewnątrz. A inni 
przeszukiwali i przebiegali zakątki, strażnice i lochy. Jedni przynosili Panu jeden od drugiego więzy, inni pętali tyrana nierozwiązywalnymi więzami, jeszcze inni rozwiązywali związanych od wieków; jedni wydawali rozkazy, inni zaś jak najszybciej je wykonywali; jedni poprzedzali biegiem wchodzącego do wewnątrz Pana, inni zaś szli w ślad za nim jako zwycięskim królem i Bogiem. [...] wszyscy krzyczeli, czynili wrzawę i byli poruszeni” (460C-D).

Również trzymany w więzach i pilnie strzeżony Adam usłyszał kroki Pana wchodzącego do więźniów i poznał Jego głos, gdy Ten szedł przez więzienie, a zwróciwszy się do wszystkich tam od wieków uwięzionych, zaczął mówić, na co w długim monologu odpowiedział mu Chrystus.

Adam: „Słyszę kroki kogoś wchodzącego do nas; a jeżeli on rzeczywiście uznał za godne tu się pojawić, to my zostaniemy uwolnieni z otchłani. Jeżeli rzeczywiście jego wśród nas zobaczymy, jesteśmy wykupieni z otchłani (zobaczywszy zaś wchodzącego Chrystusa, uderzył się w piersi i z przerażenia zawołał): Pan mój ze wszystkimi”!

Chrystus: „I z duchem twoim! (I wziąwszy go za rękę) Zbudź się, śpiący, i powstań z martwych, objawia ci się Chrystus. Ja, twój Bóg, który z twojego powodu stał się twoim synem, który z powodu ciebie i tych, którzy od ciebie [pochodza] teraz mówię, z wielką mocą zwracam się do tych, którzy są w więzach: Wyjdźcie!; tym którzy w ciemnościach: Bądźcie oświeceni!; tym którzy leżą: Powstańcie! Tobie rozkazuję: Obudź się, śpiący! Nie dlatego bowiem cię stworzyłem, abyś był trzymany w otchłani jako więzień. Powstań z martwych: Ja jestem Życiem umarłych. Powstań, moje stworzenie, powstań, mój obrazie, stworzony na moje podobieństwo. Zbudź się, idźmy stąd; ty bowiem we mnie, a ja w tobie, stanowimy jedną i nierozdzielną osobę. Z twojego powodu ja, twój Bóg, stałem się twoim synem. Z twojego powodu ja, twój Pan, przyjąłem postać sługi. Z twojego powodu ja, który jestem na wysokościach nieba, zszedłem na ziemię i pod ziemię. $Z$ twojego powodu stałem się jako człowiek bez pomocy, lecz wolny pośród zmarłych. Z powodu ciebie, który wyszedłeś z ogrodu zostałem z ogrodu wydany Żydom i w ogrodzie zostałem ukrzyżowany. Spójrz na plwociny na mojej twarzy, które z twojego powodu przyjąłem, aby cię przywrócić do pierwotnego stanu. Spójrz na ślady uderzeń na moich szczękach, które otrzymałem, aby twoją odmienioną postać przywrócić do mojej podobizny. Spójrz na ślady biczowania na moim grzbiecie, które otrzymałem, aby rozproszyć brzemię twoich grzechów, spoczywające na twoim grzbiecie. Spójrz na moje ręce godnie przebite na drzewie [Krzyża] gwoździami, z powodu ciebie, który niegodnie wyciagnąłeś rękę ku drzewu. Spójrz na moje stopy, przebite gwoździami i przekłute na Krzyżu z powodu twoich stóp, szpetnie biegnących ku drzewu nieposłuszeństwa szóstego dnia, w którym zapadł wyrok trudziłem się o nowe ukształtowanie ciebie i otwarcie raju. Skosztowałem z twojego powodu żółci, aby uleczyć w tobie przez to słodkie pożywienie gorzką przyjemność. Skosztowałem octu, aby zniszczyć 
cierpkość twojej śmierci i przeciwny naturze kielich. Przyjąłem gąbkę, aby zmazać rejestr twoich grzechów. Przyjąłem trzcinę, aby podpisać wolność rodowi ludzkiemu. Zasnąłem na Krzyżu i mój bok został przeszyty włócznią z powodu ciebie, który zasnąłeś w raju i wyjąłeś Ewę z [twojego] boku. Mój bok uleczył ból [twojego] boku. Mój sen wydobędzie cię ze snu w otchłani. Moja włócznia powstrzymała włócznię zwróconą przeciwko tobie. A więc zbudź się, ruszajmy stąd. Wróg wyprowadził cię z raju; ja posadzę cię już nie w raju, lecz na tronie niebieskim. Zabroniłem ci dostępu do drzewa, symbolu życia, a oto ja sam, Życie, zjednoczyłem się z tobą. Postawiłem cherubinów, aby ciebie jak niewolnicy strzegli; a [teraz] sprawiam, że cherubiny oddają ci cześć Boską. Kryłeś się przed Bogiem jako nagi; a oto ukryłeś w sobie samym nagiego Boga. Przywdziałeś skórzane okrycie wstydu; a ja będąc Bogiem przywdziałem krwawe okrycie twojego ciała. Dlatego zbudźcie się, wyruszajmy stąd, od śmierci ku życiu, od zepsucia ku niezniszczalności, od cienia ku wiecznemu światłu. Obudźcie się, chodźmy stąd, od bólu ku zadowoleniu, od niewoli ku wolności, od więzienia ku górnemu Jeruzalem, od więzów ku wyzwoleniu, od uwięzienia ku rajskiej rozkoszy, od ziemi ku niebu. Dlatego bowiem umarłem i zmartwychwstałem, aby władać umarłymi i żywymi. Obudźcie się, ruszajmy stąd. Ojciec mój Niebieski oczekuje bowiem zgubionej owcy. Dziewięćdziesiąt dziewięć owiec-aniołów oczekuje na Adama, kiedy powstanie, kiedy wyjdzie i przyjdzie do Boga. Tron cherubinów jest gotowy, słudzy czujni i gotowi, komnata weselna przygotowana, potrawy gotowe. Wieczne namioty i siedziby gotowe. Skarbce dóbr zostały otwarte, Królestwo Niebieskie od wieków jest przygotowane: «ani oko nie widziało, ani ucho nie słyszało, ani serce człowieka nie zdołało pojąć» (1Kor $2,9)$ dóbr, które oczekują na człowieka" (461A - 464C).

Po tych słowach wstaje Adam wraz z Ewą i tysiącami sprawiedliwych przetrzymywanych od wieków w otchłani i wychodzą z Chrystusem, cała zaś homilia kończy się tradycyjną doksologią.

$$
* * *
$$

Przyglądając się bliżej zaprezentowanym wyżej wybranym tekstom dramatyzowanych homilii patrystycznych, zwłaszcza tym ostatnim o zstapieniu Chrystusa do otchłani, odnosimy zapewne wrażenie, że czytamy jakąś Pasję Chrystusa, albo oglądamy przedstawiany na scenie jakiś dojrzały dramat pasyjny o Jego męce i śmierci. W tekstach tych bowiem, jakby na scenie, prezentowana jest (choć wschodnia literatura patrystyczna, także liturgiczna, nie pozostawiła nam żadnych przepisów wykonawczych na ten temat) żywa akcja dramatyczna: na tle chóru, który ją komentuje, aprobuje lub potępia, pojawiają się i wymieniają aktorzy, prowadzący między sobą ożywiony pełen ekspresji i wyrażający całą gamę uczuć dialog, a są to w sumie istotne elementy składające się na starożytne pojęcie dramatu, który ongiś zdefiniował Arystoteles, 
a w okresie patrystycznym, m.in. w 1. poł. III w. Orygenes, komentując Pieśń nad Pieśniami, będąca, jego zdaniem, „pieśnią weselną, napisaną na sposób dramatu" (nuptiale carmen; dramatis in modum conscriptum) [...]. Dramat zaś, który jako sztukę winno się grać na scenach, ma miejsce wówczas, gdy wprowadza się różne osoby, a podczas gdy jedne wchodzą [na scenę], a inne wychodzą, tekst sztuki wypowiadany jest przez różne osoby i kierowany do różnych osób" ${ }^{48}$. Nietrudno zauważyć, że te właśnie elementy (zmiana aktorów, ruch, dialog) przejawiają się wyraźnie w cytowanych fragmentach dramatyzowanych w pełni homilii, które zasadnie można już nazwać zalążkami dramatu chrześcijańskiego; mówimy tu „chrześcijańskiego”, bo ich fabuła nie jest zaczerpnięta, jak w dramacie klasycznym z mitologii lub życia codziennego, lecz z Biblii i prawd chrześcijańskich. Przyjmuje się ogólnie, iż zrodził się on na Zachodzie w IX-X w. z dramatu liturgicznego, którego początki wywodzone są znów z liturgicznych tropów łacińskich, a zwłaszcza z tzw. Troparium Sangalianum, czyli krótkiego dialogu niewiast z aniołami przy pustym grobie Chrystusa (Visitatio sepulcri):

„Kogo, chrześcijanki, poszukujecie w grobie?”

„Ukrzyżowanego Jezusa Nazareńskiego, niebianie”.

„Nie ma Go tu, zmartwychwstał, jak zapowiedział,

Idźcie i rozgłaszajcie, że powstał z grobu,

Zmartwychwstał"49.

Wydaje się jednak, że dramat chrześcijański, zwłaszcza na Wschodzie, zaczął się krystalizować o wiele wcześniej, bo już w patrystycznej homilii dramatyzowanej, której początków należy szukać w Syrii już w IV w. w memrach

${ }^{48}$ Por. Origenes, In Canticum canticorum. Prologus 1, 1-3 interprete Rufino, PG 13, 61-63, SCh 375, 80-82: „Drama enim dicitur, ut in scaenis agi fabula solet,ubi diversae personae introducuntur et, aliis accedentibus, aliis etiam discedentibus, a diversis et ad diversos textus narrationis expletur", thum. S. Longosz: Teoria dramatu w pismach autorów wczesnochrześcijańskich. Wstęp, wybór tekstów, opracowanie i noty, w: O dramacie. Od Arystotelesa do Goethego. Poetyki-Manifesty-Komentarze, red. E. Udalska, Warszawa 1989, PWN, 134; por. thum. Kalinkowski: Orygenes, Komentarz do Pieśni nad pieśniami, Kraków 1994, 7; zob. też tamże I 1, 1, PG 13, 83C, tłum. S. Kalinkowski, s. 37: „Moim zdaniem Salomon napisał epitalamium, czyli pieśń weselną w formie utworu scenicznego: pieśn tę włożył w usta wychodzącej za mąż Oblubienicy, pałającej niebieską miłością do swego Oblubieńca, którym jest Słowo Boże [...]. A zatem Oblubienica zwraca się nie tylko do Oblubieńca, lecz również do dziewcząt, a Oblubieniec przemawia nie tylko do Oblubienicy, lecz również do swych przyjaciół. Na tym właśnie polega to, o czym powiedzieliśmy wyżej - mianowicie, że pieśń weselna została napisana w formie dramatu. Dramatem zaś nazywamy utwór odgrywany na scenie przez różne postacie: jedne wchodzą na scenę, inne wychodzą, a tekst sztuki wypowiadany jest przez różne osoby i skierowany do różnych osób"; zob. L. Perrone, ,, The Bride at the Crossroads”. Origen's Dramatic Interpretation of the Song of Songs, EThL 82 (2006) 69-102, spec. 81-85 („Dramatis in modum”. The Song of Songs as Play); M.I. Danieli, Origene lettore del Cantico, „Nicolaus” 35 (2008) fasc. 2, 99-114.

${ }^{49}$ Antiphonae cum responsoriis de vigilia sanctissimae Paschae: Ad Invitatorium, PL 78, 769; por. C. Flanigan, The Roman Rite and the Origins of the Liturgical Drama, „University of Toronto Quarterly” 43 (1973-1974) 263-284; Longosz, Zalażki dramatu chrześcijańskiego, s. 266-267. 
i sugithach św. Efrema $(† 373)$, a potem Narsaja $(† 507)^{50}$, a jej popularności i rozkwitu $\mathrm{w}$ V-VII wieku ${ }^{51}$. Te zaś wschodnie dramatyzowane homilie o zstąpieniu Chrystusa do otchłani mogły w jakiś sposób wpłynąć (choć niezupełnie treściowo) na wielkanocny cykl zachodniego średniowiecznego dramatu liturgicznego, zwłaszcza na również odprawianą ceremonię prezentowania descensio ad infernos; odprawiano ją zazwyczaj przed jutrznią rezurekcyjną: celebrans niosąc krzyż z choragwią Pańską i śpiewając antyfonę „Cum rex gloriae” udawał się w procesji do zamkniętych drzwi kościoła, w które trzykrotnie uderzał ramionami krzyża, przy wtórze śpiewanej przez lud antyfony „Tollite portas”, na znak uwolnienia dusz z czyśćca. W niektórych miejscach (np. w klasztorze benedyktynek w Barking k. Londynu w XV w.) zamykano na ten czas w kaplicy grupę zakonnic lub kleryków, wyobrażających przetrzymywane w czyśćcu dusze zmarłych, których po antyfonie i otwarciu drzwi wprowadzano do kościoła, kierując się z nimi procesjonalnie do grobu z palmami i świecami na znak zwycięstwa nad śmiercią i szatanem ${ }^{52}$. Nieco inaczej, ale chyba bardziej ciekawie i dramatycznie, ceremonia ta, przedstawiana była w homiliach na Wschodzie.

Dla całości problemu wypadałoby tu też zaprezentować bogata grupę greckich dramatyzowanych homilii o Zwiastowaniu (wybrano 8 homilii), którą ze względu na brak miejsca przedstawimy przy innej okazji. Te jednak, jak zobaczymy, nie znalazły tak bogatego odzwierciedlenia w tematyce zachodniego dramatu liturgicznego (nie stworzono tu też żadnego cyklu zwiastowaniowego), choć i tu można znaleźć pewne ślady jego prezentowania przed lub podczas uroczystej Mszy świętej w samo święto (25 III) w postaci dialogu archanioła Gabriela z Maryją (niekiedy z dodatkiem nawiedzenia św. Elżbiety, czy z wprowadzeniem postaci św. Józefa), ale dopiero w XIII-XIV wieku.

\section{DRAMATIZED PATRISTIC HOMILIES AS ORIGIN OF CHRISTIAN DRAMA}

\section{(Summary)}

The author of this paper tries to prove that the origins of Christian drama shouldn't be sought in Latin liturgical drama crystalized in $9^{\text {th }}$ and $10^{\text {th }}$ century - as it is commonly accepted - but rather much earlier: in Eastern dramatized patristic homilies of $5^{\text {th }}, 6^{\text {th }}$ and $7^{\text {th }}$ century. All fully dramatized homilies of those days are arranged in three groups:

1. The homilies about John the Baptist and the Baptism of Jesus Christ;

2. The homilies about descending of Jesus Christ into the abyss and liberation of those who are righteous from hell;

\footnotetext{
${ }^{50}$ Por. Longosz, Półdramatyczne homilie patrystyczne, s. 422-437.

${ }^{51}$ Por. tenże, Zalażki dramatu chrześcijańskiego, s. 270-271.

${ }^{52}$ Por. J. Okoń, Dramat liturgiczny, EK IV, Lublin 1983, 186.
} 
3. Homilies about the Annunciation of Blessed Virgin Mary - most numerous texts.

In this article only homilies from group 1 and group 2 are analyzed. The eight most dramatized speeches from these two groups were chosen. From these homilies some fragments or full parts of dialogs are chosen and quoted, as examples of dramatic action, shown in the clearest way (containing the fullness of psychological expression and motion, rhetorically built dialogs of Biblical characters). These parts are explained and commented in the context of the idea of drama proposed by Origen (Commentarius in Cantica Canticorum. Prologus 1, 1-3; I 1, 1-2).

From Group 1, the author of this article presents two homilies: Homilia in Sanctam Theophaniam (which authorship is mistakenly assigned to St. Gregory the Wonderworker) and Homilia de baptismo Christi [CPG 5520] of PseudoEusebius of Alexandria.

From Group 2 six speeches are chosen. Five of them are written by PseudoEusebius of Alexandria. They make specific cycle, known as Eusebian cycle of descending Christ into the abyss. This cycle - in its contents and structure - is a rhetorical amplification of apocryphal Evangelium Nicodemi (17-27) and Quaestiones S. Bartholomaei Apostoli (I 1-9). These homilies are summarized by the author of this paper. These five Eusebian homilies are completed with well-known Homilia de divini corporis sepultura et de Christi adventu in infernum [CPG 3768] of anonymous author. This last one is quoted on the Holy Saturday in the Liturgy of the Hours (II 386-388). According to some modern authors (i.e. G. La Piana), all these six homilies seem to set up the Christian Passion Drama in three acts (A-C).

The structure of this drama is as follows. At the beginning we have well documented theological introduction about descensus in inferos. Then we have three acts with following homilies (first five of them are written by Pseudo-Eusebius of Alexandria):

A. Descending of John the Baptist to the abyss to prepare those who are righteous for the coming of Christ: Homilia in illud: „, Tu es qui venturus es, an alium exspectamus" [CPG 5521] and Homilia de adventu Joannis in infernum et de ibi inclusis [CPG 5522];

B. The Judas' betrayal, imprisonment of Jesus and the dread of rulers of the underworld - Satan and Hades - after they have heard about coming of Christ: De proditione Judae [CPG 5523] and Homilia in Diabolum et Hadem [CPG 5524];

C. The Passion and Death of Christ and his descending into the abyss: Homilia de Christi passione [CPG 5526] and Homilia in divini corporis sepultura et de Christi adventu in infernum [CPG 3768].

The numerous and widely presented fragments of dramatized homilies - completed with highly quoted literature of subject - seem to convince clearly, that the origins of Christian drama (reconstructed in unspecified way during the liturgy in the Church) could be reasonably sought as far as in patristic dramatized homily of $6^{\text {th }}$ and $7^{\text {th }}$ century. 
Key words: Patristic Homilies, Christian Drama, Ps-Eusebius of Alexandria.

Słowa kluczowe: Homilie patrystyczne, dramat chrześcijański, Ps-Euzebiusz z Aleksandrii.

\section{BIBLIOGRAFIA}

\section{Źródła}

Ambrosius, Expositio Evangelii secundum Lucam, ed. M. Adriaen, CCL 14, Tournhout 1957, tłum. W. Szołdrski, wstęp i oprac. A. Bogucki, PSP 16, Warszawa 1977.

Antiphonae cum responsoriis de vigilia sanctissimae Paschae: Ad Invitatorium, PL 78, 769.

Augustinus, De haeresibus, ed. L.G. Müller: The „De haeresibus” of St Augustine, Washington 1956.

Clemens Alexandrinus, Stromata Stromata, ed. L. Früchtel, GCS 52, Berlin 1960, tłum. J. Niemirska-Pliszczyńska: Klemens Aleksandryjski, Kobierce zapisków filozoficznych dotyczacych prawdziwej wiedzy, I-II, Warszawa 1994.

Cyrillus Hierosolymitanus, Catecheses, PG 33, 331-1060, tłum. W. Kania, BOK 14, Kraków 2000, 31-318.

Eusebius EMESEnus, Oratio de proditione Judae, PG 86, 525-536.

Evangelium Bartholomaei I 9-20, ed. J.D. Kaestli - P. Cherex, Apocryphes 1, Turnhout 1993, 27-142, 254-356 (przekład francuski), tłum. R. Bartnicki, oprac. M. Starowieyski: Zapytania Barttomieja, w: Apokryfy Nowego Testamentu, I 2, wyd. 2, 757-775; tekst łaciński ed. U. Moricca, w: tenże, Un nuovo testo dell'Evangelio di Bartolomeo, RB 31 (1922) 20-30 (tekst łaciński).

Evangelium Nicodemi pars III, ed. C. Tischendorf: Evangelium Nicodemi, pars III sive Descensus Christi ad inferos, w: Evangelia apocrypha, Leipzig 1876, repr. Hildesheim 1966, 323-332; lub ed. H.C. Kim: The Gospel of Nicodemus, Toronto 1973, tłum. i oprac. M. Starowieyski: Ewangelia Nikodema, cz. III: Zstapienie do otchłani, w: Apokryfy Nowego Testamentu, I 2, wyd. 1, Lublin 1980, 445-451; wyd. 2, Kraków 2003, 653-665.

Filastrius Brixensis, Diversarum haereseon liber, ed. F. Heylen CCL 9, Turnhout 1957, 207-324.

Gregorius Magnus, Registrum epistularum, ed. D. Norberg, CCL 140, Tournhout 1982.

Gregorius Nazianzenus, Oratio 43 (In laudem Basilii Magni), PG 36, 493-606, thum. anonimowe, w: Św. Grzegorz z Nazjanzu, Mowy wybrane, Warszawa 1967, 476-523 (Na cześć Bazylego, biskupa Cezarei Kapadockiej).

Hieronymus, Commentarii in Matthaeum, PL 26, 15-218, thum. J. Korczak: Komentarz do Ewangelii wedtug św. Mateusza, ŹMT 46, Kraków 2008.

Hieronymus, Epistula 121 (Ad Aglasiam, de quaestionibus XI), tłum. J. Czuj, ŹMT 63, Kraków 2011, 81-114.

Hippolytus, De Christo et Antichristo, ed. N. Bonwetsch - H. Achelis, GCS 1, Leipzig 1897 lub PG 10, 725, tłum. S. Kalinkowski, ŹMT 17, Kraków 2000.

Homilia in divini Corporis sepulturam et de Christi adventu in infernum, PG 43, 439-463, thum. LG II, 386-388 (Starożytna homilia na Święta i Wielką Sobotę).

Homilia in sanctam Theophaniam sive de Christi baptismo, PG 10, 1177-1190.

In sancta et magna Parasceve et in sanctam Passionem Domini, PG 62, 721-724 
JoAnnes Chrysostomus, In Matthaeum hom. 36, PG 57, 414-420, tłum. J. Krystyniacki, ŹMT 18, Kraków 2000, 421-428.

Maximus Turonensis, Sermo 61 (In natalem S. Joannis Baptistae), PL 57, 653-658.

Origenes, Commentarium in Evangelium Joannis, ed. C. Blanc, SCh 120, t. 1 : Livres I-V, Paris 1982, tłum. S. Kalinkowski, PSP 28/1, Warszawa 1981, 49-155.

Origenes, Homilia in I Regum 28, 3-25, ed. E. Klostermann, GCS 6, Leipzig 1901, 283 294; lub PG 12, 1012-1028.

Origenes, Homiliae in Lucam, hrsg. M. Rauer, GCS 49, Leipzig 1958; lub ed. H. Crouzel - F. Fournier - P. Périchon, SCh 87, Paris 1962, thum. S. Kalinkowski, PSP 36, Warszawa 1986.

Origenes, In Canticum canticorum. interprete Rufino, PG 13, 37-198; lub ed. O. Rousseau, SCh 37, Paris 1953, tłum. S. Kalinkowski: Orygenes, Komentarz do Pieśni nad pieśniami, Kraków 1994, 7-189; lub tłum. S. Longosz [fragm. Prologus 1, 1-3]: Teoria dramatu w pismach autorów wczesnochrześcijańskich. Wstęp, wybór tekstów, opracowanie i noty, w: O dramacie. Od Arystotelesa do Goethego. PoetykiManifesty - Komentarze, red. E. Udalska, Warszawa 1989, 134.

Praedestinatus, PL 53, 587-672.

Ps-Eusebius Alexandrinus, Homilia [XII] in illud: „,Tu es qui venturus es, an alium exspectamus?", PG 86, 380-384.

Ps-Eusebius Alexandrinus, Homilia [XIII] de adventu Joannis in infernum et de ibi inclusis, PG 86, 509-525.

Ps-Eusebius Alexandrinus, Homilia [XIV] de proditione Judae, PG 86, 525-536.

Ps-Eusebius Alexandrinus, Homilia [XV] in Diabolum et Hadem (= Orcum), PG 86, 383-406.

Ps-Eusebius Alexandrinus, Homilia [XVII] de Christi Passione, PG 62, 721-724.

Ps-Eusebius Alexandrinus, Homilia de baptismo, PG 86, 372-380, tłum. T. Krynicka, w: S. Longosz, Półdramatyczne homilie patrystyczne, w: W postudze Słowa Pańskiego. Księga Pamiatkowa ks. prof. J. Kudasiewicza, Kielce 1997, 72-75.

Rufinus, Expositio Symboli, ed. M. Simonetti, CCL 20, Tournhout 1961, 125-182.

Sophronius Hierosolymitanus, Oratio 7 [Encomium in S. Joannem Praecursorem], PG 87, 3321-3354.

Vita Eusebii Alexandrini, PG 86, 297-309.

\section{Opracowania}

Aldama J.A. De, Repertorium pseudochrysostomicum, Paris 1965.

Augusti J.C.G., Eusebii Emeseni oratio in sacrum Parasceves diem e duobus codicibus Vindobonensibus nunc in primum in lucem edita, Bonn 1820.

Augusti J.C.G., Eusebii Emeseni quae supersunt opuscula graeca ad fidem codicum

Vindobonensium et editionum diligenter expressa, Elberfeld 1829.

BeEston A.P.L., The „Quaestiones Bartholomae”, JTS 25 (1974) 24-127.

Bendinelli G., Origene e il ,, descensus ad inferos”, „Divus Thomas” 104 (2001) 183-210.

Brottier L., Le prédicateur émule du prophète ou rival de l'acteur?, CPE 1999, nr 74, 2-19.

Callon P., Descente du Christ aux enfers, w: Catholicisme III 658-661.

CAPERAn L., Le problème du salut des infédeles. Essai historique, I, Paris 1912, 51-132.

Connell M.F., „Descensus Christi ad inferos”. Christ's Descend to the Dead, ThS 62 (2001) 262-282.

Connolly R.H., The Early Syriac Creed, ZNW 7 (1906) 202-223. 
Dalton J.W., Christ's Proclamation to the Spirits. A Study of 1 Peter 3:18 - 4:6, Analecta Biblica 23, Roma 1965.

Danieli M.I., Origene lettore del Cantico, „Nicolaus” 35 (2008) fasc. 2, 99-114.

EsBroeck M. VAN, Les plus anciens homéliaires géorgiens, Louvain 1980.

Flanigan C., The Roman Rite and the Origins of the Liturgical Drama, „University of Toronto Quarterly" 43 (1973-1974) 263-284.

Galot J., La Descente du Christ aux enfers, NRTh 83 (1961) 481-482.

Gounelle R., La Descente du Christ aux enfers, Paris 2000.

GóźDź K., „,Descensus ad inferos”, „Communio” 33 (2013) z. 3, 129-140.

GrAF G., Geschichte der christlichen arabischen Literatur, Bd. I (ST 118) Übersetzungen, Città del Vaticano 1944.

Grillmeier A., Christ in Christian Tradition. From the Apostolic Age to Chalcedon (451), transl. J.S. Bowden, London 1965.

GrillmeIER A., Der Gottessohn im Totenreich. Soteriologische und christologische Motivierung der Descensuslehre in der älteren christlichen Überlieferung, ZKTh 71 (1949) 1-23.

Gronewald M., Kein durchtriebener Räuber (P. Lit. Lond. $245=$ Ps-Eusebius, Sermo 17), „Zeitschrift für Papyrologie und Epigraphik” 34 (1979) 22-25.

GstreIn H., Unedierte Texte zur Geschichte der byzantinischen Osterpredikt, Wien 1968.

Hall Harris W., The Descent of Christ, New York 1996.

Hey O., Eine Rede über Christi Höllenfahrt, „Archiv für Lateinische Lexikographie und Grammatik" 14 (1906) 253-268.

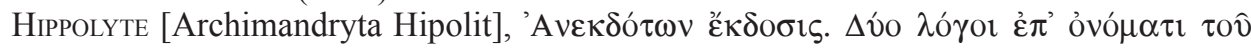

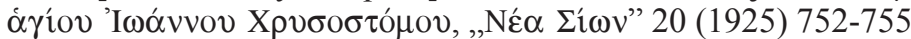

HRYNIEWICZ W., ,, Zstapienie do piekiet” w tradycji wschodniej, RTK 26 (1979) z. 3, 41-52.

Izydorczyk Z., The Medieval Gospel of Nicodemus: Texts, Intertexts and Contexts in Western Europe, Tempee Ariz 1997.

Kaestli J.D., Où en est l'étude de l'Évangile de Barthelémy, RB 95 (1988) 5-33.

Kecskeméti J., Deux caractéristiques de la prédication chez les prédicateurs pseudochrysostomiens: la répétition et le discours fictif, „Rhetorica” 14 (1996) nr 2, 15-36.

KecskemÉTi J., Doctrine et drame dans la prédication grecque, „Euphrosyne” 21 (1993) $29-67$.

KeсsкeméTi J., L’homélie dramatisée dans la prédication grecque, CPE 1999, nr 74, 20-32

KeCskeméti J., Personnages tragiques et personnages comiques dans les homélies dramatisées des prédicateurs grecs, „Euphrosyne” 22 (1994) 45-61.

Kelly J.N.D., Early Christian Creeds, London 1972, 378-383 (The Descent to Hell).

Kowalski S., Le problème de la descente du Christ aux enfers dans la I Épitre de S. Pierre, CT 21 (1949) 42-76.

Kroll J., Gott und Hölle. Der Mythos vom Descensuskampfe, Leipzig - Berlin 1932.

Kroll J., Zur Geschichte des Spieles von Christi Höllenfahrt, „Vorträge der Bibliothek Warburg (Leipzig)" 7 (1931) 257-301.

La Piana G., Le rappresentazioni sacre nella letteratura bizantina, Grottaferrata 1912.

LAFOntaine G., La version arménienne du sermon d'Eusebe d'Alexandrie ,, Sur la Passion du Seigneur”, „Le Muséon” 95 (1982) 99-113.

Lafontaine G., La version arménienne du sermon d'Eusebe d'Alexandrie „Sur la venue de Jean aux enfers”, „Le Muséon” 91 (1978) 87-104.

LAFOnTAINE G., La version arménienne du sermon d'Eusebe d'Alexandrie „, Sur la trahison de Judas”, „Le Muséon” 91 (1978) 335-353.

Lafontaine G., Les homélies d'Eusèbe d'Alexandrie, Diss., Louvain 1966. 
Lochbrunner M., Descensus ad inferos. Aspekte und Aporien eines vergessenen Glaubensartikels, MThZ 9 (1993) 161-177.

Longosz S., Dramatyzowane homilie o Janie Chrzcicielu i chrzcie Chrystusa, VoxP 23 (2003) t. 44-45, 65-75.

Longosz S., I germi del dramma cristiano nella letteratura patristica, StPatr 31 (1997) 59-69.

Longosz S., Półdramatyczne homilie patrystyczne, w: W posłudze Słowa Pańskiego. Księga Pamiatkowa ks. prof. J .Kudasiewicza, Kielce 1997, 422-437.

Longosz S., Struktura Symbolu Apostolskiego, w: Symbol Apostolski w nauczaniu i sztuce Kościoła do Soboru Trydenckiego, red. R. Knapiński, Lublin 1997, 77-98.

Longosz S., Zalażki dramatu chrześcijańskiego w literaturze patrystycznej, RH 44 (1996) z. 3, 263-273.

MaAs W., Gott und Hölle. Studien zum Descensus Christi, Erlangen 1979.

MacCoull L.S.B., Who was Eusebius of Alexandria?, „Byzantinoslavica” 60 (1999) 9-18.

MAI J.A., Spicilegium Romanum, vol. 9, Roma 1843.

McCulloch J.A., The Harrowing of Hell. A Comparative Study of an Early Christian Doctrine, Edinburgh 1930.

MeJzner M., „Zstapienie do piekiet” w starożytności chrześcijańskiej, „Communio” 31 (2011) z. 2, 90-108

Montfaucon B. De, Sancti Patris nostri Johannis Chrysostomici... opera omnia quae exstant, vol. 11, Paris 1734.

Moricca U., Un nuovo testo dell'Evangelio di Bartolomeo, RB 30 (1921) 481-516.

Nersessian S. Der, An Armenian Version of the Homilies on the Harrowing of Hell, DOP 8 (1954) 203-224.

Nosol A., ,Zstapit do piekiet”, AK 98 (1982) 170-178.

ОкоŃ J., Dramat liturgiczny, EK IV, Lublin 1983, 183-188.

PERADZE G., Die altchristliche Literatur in der georgischen Überlieferung, III, OC 5 (1930) $80-98$.

Peretto E., Discesa agli inferi, DPAC I 989-991.

Perkins P., The Gnostic Dialogue. The Early Church and the Crisis of Gnosticism, New York 1980.

Perrone L., ,, The Bride at the Crossroads”. Origen's Dramatic Interpretation of the Song of Songs, EThL 82 (2006) 69-102.

Pietras H., Kerygmatyczna treść formuly „Zstapit do piekiet” u pierwszych Ojców, w: Ewangelizacja w epoce patrystycznej. Zagadnienia wybrane, red. F. Drączkowski - J. Pałucki, Lublin 1994, 103-123.

Piotrowski S., Teologiczne treści formuły „Zstapił do piekiet”, „Wiadomości Kościelne Archidiecezji w Białymstoku" 18 (1992) 71-77.

Rand E.K., Sermo de confusione Diaboli, „Modern Philology” 2 (1904) 261-278.

Rubinkiewicz R., ,Duchy zamknięte $w$ więzieniu”. Interpretacje 1P 3, 41 9-20 w świetle Hen 10, 4, 2, RTK 28 (1981) z. 1, 77-86.

Sauget J.M., Deux Homéliaires Syriaques de la Bibliothèque Vaticane. Syriaque 569 n. 37, OCP 27 (1961) 387-421.

Sauget J.M., L'Homéliaire arabe de la Bibliothèque Ambrosienne (X. 198 Sup.) et ses membra disiecta, AnBol 88 (1970) 459-460.

Sauget J.M., La version arabe de l'homélie „Sur la trahison de Judas” d'Eusébe d'Alexandrie, „Le Muséon” 92 (1979) 5-23.

SAviLius H., S. Joannis Chrysostomici opera graece, vol. VII, Paris 1612.

Schulz H.J., Die „Höllenfahrt” als Anastasis, ZKTh 81 (1959) 1-66. 
SHeErin D., St. John the Baptist in the Lower World, VigCh 30 (1976) 1-22.

Simonetti M., Praecursor ad inferos. Una nota sull'interpretazione patristica di Matteo 11, 3, „Augustinianum” 20 (1980) 369-371.

Skrzyniarz S., Hades. Recepcja, sens ideowy i przemiany obrazu pogańskiego boga w sztuce bizantyńskiej, Kraków 2002.

Starowieyski M., Wprowadzenie, w: Apokryfy Nowego Testamentu, I 2, Kraków 2003, 634.

Starowieyski M., Zapytania Bartłomieja. Wprowadzenie, w: Apokryfy Nowego Testamentu, I 2, Kraków 2003, 755-757.

TEIXIDOR J., La descente aux Enfers chez saint Éphrem, „L'Orient Syrien” 6 (1961) 25-40.

Thilo T.C., Ueber die Schriften des Eusebius von Alexandrien und des Eusebius von Emisa, Halle 1832.

Vaillant A., L'homélie d'Epiphane sur 1'ensevelissement du Christ. Texte vieux-slave, texte grec et traduction francaise, Zagreb 1958.

VIs H. DE, Homélie cathédrale de Marc patriarche d'Alexandrie, „Le Muséon” 34 (1921) $179-216$; 35 (1922) 17-48.

Wilmart A.- Tisserant E., Fragments grecs et latins de l'Évangile de Barthélémy, RB 10 (1913) 161-190, 321-368.

ZająC R.- Dola T., Zstapienie Chrystusa do otchtani, EK XX 1485-1488.

Zellinger J., Studien zu Severian von Gabala, Münsterische Beiträge zur Theologie 8, Münster 1926, 142-146. 
